\title{
Small shelly fossils from the Montezuman-Delamaran of the Great Basin in Nevada and California
}

\author{
Thomas Wotte ${ }^{1}$ and Frederick A. Sundberg ${ }^{2}$ \\ ${ }^{1}$ Institut für Geologie und Mineralogie, Universität zu Köln, Zülpicher Str. 49a, D-50674 Köln, Germany 〈thomas.wotte@uni-koeln.de〉 \\ ${ }^{2} 821$ E. Pine Ln., Show Low, AZ 85901, USA 〈freddeb85@ cableone.net)
}

\begin{abstract}
The mixed carbonate-siliciclastic successions of the Cambrian Series 2-Cambrian Series 3 interval of the Great Basin are well investigated in respect to their trilobite and brachiopod fauna. In contrast, the small shelly fossils have been mostly unreported. Nine sections in eastern California and southern Nevada have produced a small shelly assemblage of low diversity, which likely reflects non-phosphatization and loss of originally calcareous remains. From the Montezuman-Delamaran stages we report Anabarella chelata Skovsted, 2006a, Costipelagiella nevadense Skovsted, 2006a, Pelagiella aff. P. subangulata (Tate, 1892), Microcornus sp., Parkula sp., Hyolithellus? sp., Allonia sp., Chancelloria sp., Archiasterella cf. A. hirundo Bengtson in Bengtson et al., 1990, Archaeooides cf. A. granulatus Qian, 1977, and undefined echinoderms and helcionelloid molluscs. The lower part of the Montezuman Stage delivered a number of lobopodian sclerites as Microdictyon rhomboidale Bengtson, Matthews, and Missarzhevsky, 1986, Microdictyon montezumaensis n. sp., and Microdictyon cuneum n. sp. The occurrence of $P$. aff. $P$. subangulata and species of Microdictyon in the lower Montezuman Stage offers a fundamental potential for correlation with the base of Cambrian Series 2/Stage 3 of South China, Siberia, and Avalonia.
\end{abstract}

\section{Introduction}

The Great Basin of western United States contains the most complete and well-exposed sections covering the Cambrian Series 2-Series 3 interval (Montezuman-Marjuman stages of the Laurentian nomenclature; Palmer, 1998). These highly fossiliferous, mixed carbonate-siliciclastic successions have been extensively investigated for their trilobite and brachiopod faunas (e.g., Rowell 1966, 1977, 1980; Rowell and Henderson, 1978; Palmer and Halley, 1979; Sundberg and McCollum, 1997, 2000, 2003a, b; Hollingsworth 2005, 2011a, b; Streng and Holmer, 2006; Sundberg, 2011; Webster, 2011a). However, other faunal elements, especially small shelly fossils (SSFs), are generally unconsidered. These SSFs provide important information for biostratigraphic, depositional environment, and paleoecologic reconstructions (e.g., Geyer, 1986; Elicki, 1994, 2005, 2006; Geyer and Shergold, 2000; Gubanov, 2002; Steiner et al., 2007).

Few, non-brachiopod, SSFs have been reported in detail from the Great Basin. Tubes of uncertain affinity and the hyolith Salanytheca sp. occur in the pre-trilobitic Cambrian Deep Spring Formation of western Nevada and eastern California (Signor et al., 1987). The agglutinated protist Platysolenites antiquissimus Eichwald, 1860, chancelloriid sclerites, helicoplacoid ossicles, and hyoliths occur in the Montezuman Stage of Indian Springs Canyon (Fig. 1; Streng et al., 2005; English and Babcock, 2010). Hyolithellus insolitus Grigorieva in Voronin et al., 1982, Sphenotallus sp., echinoderm ossicles, and sponge spicules were described from the lower Dyeran Harkless Formation of Gold Point (Fig. 1; Skovsted and Holmer, 2006).
Furthermore, the helcionelloid molluscs Anabarella chelata Skovsted, 2006a and Costipelagiella nevadense Skovsted, 2006a, the hyolith Parkula esmeraldina Skovsted, 2006a, and remains of echinoderms, chancelloriids, and sponges occur in the uppermost Dyeran Stage from the basal Emigrant Formation of Split Mountain (Fig. 1; Skovsted, 2006a). The lower Cambrian hyolith fauna originally described by Walcott (1886) and Resser (1938) from Nevada were reinvestigated by Malinky (1988).

Most recent report of SSFs from the Great Basin only mentioned their presence without any illustration, systematic documentation, and/or detailed stratigraphic distribution. Hollingsworth (2011b) and Hollingsworth and Babcock (2011) reported the hyolith "Ladatheca" cylindrica Grabau, 1900, orthothecid hyoliths, and the bradoriid Dielymella? Ulrich and Bassler, 1931 from the Montezuman Stage and the lower unnamed stage of the Indian Springs Canyon and Montezuma Range sections (Fig. 1). Webster (2011c) mentioned pelagiellids, hyoliths, and chancelloriids from the upper Dyeran from a variety of sections in Nevada. Sundberg and McCollum (1997, 2003a) and McCollum et al. (2011) mentioned Stenothecoides elongata Walcott (1886) and Latouchella arguta Resser (1939) and hyoliths, echinoderms, and chancelloriids from the lower Delamaran Stage of Nevada.

The purpose of this report is to document a new small shelly assemblage from a variety of Montezuman-Delamaran mixed carbonate-siliciclastic successions of eastern California and southern Nevada in order to increase the knowledge of the paleogeographic and biostratigraphic potential of these faunal elements. 


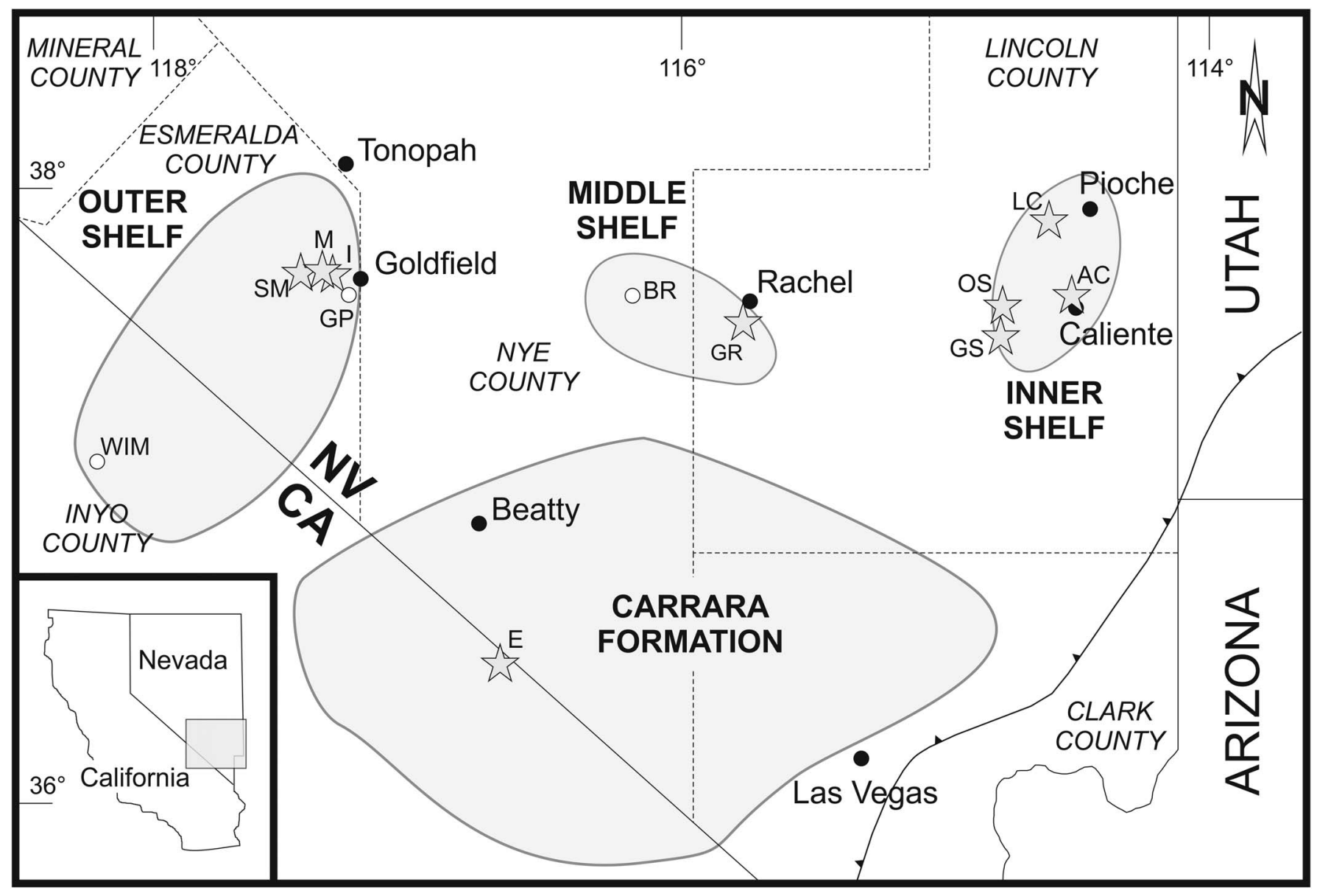

Figure 1. Map of the southern Great Basin, showing the facies realms of the inner, middle, and outer shelf (modified from Palmer and Halley, 1979; Sundberg and McCollum, 2000, 2003a; McCollum and McCollum, 2011; Sundberg, 2011; Webster, 2011a). Shaded stars mark the sections investigated: AC, Antelope Canyon; E, Echo Canyon; GR, Groom Range; GS, Grassy Spring; I, Indian Springs Canyon; LC, Log Cabin Mine; M, Montezuma Range; OS, Oak Spring Summit; SM, Split Mountain. White circles represent localities mentioned in the text: BR, Belted Range; GP, Gold Point; WIM, White-Inyo Mountains.

\section{General geology and stratigraphy}

The Montezuman-Delamaran succession of the Great Basin reflects the overall flooding of the western margin of the Laurentian craton (Webster, 2011a). During this time the shelf was spatially and temporally heterogeneous, as documented by the multitude of regional lithostratigraphic units (e.g., Palmer and Halley, 1979; Sundberg and McCollum, 2003b; Webster, 2011a, b; Figs. 1, 2). Based on lithofacies and trilobite distribution patterns, the depositional environment is separated into inner, middle, and outer shelf facies realms (e.g., Stewart, 1970; Palmer and Halley, 1979; Sundberg and McCollum, 2003a; McCollum and McCollum, 2011; Sundberg, 2011; Webster, 2011a; Figs. 1, 2).

Inner shelf facies.-Sections of the inner shelf facies are primarily exposed in the Pioche-Caliente area of eastern Nevada (Fig. 1). The Dyeran-Delamaran boundary interval is represented by the Pioche Formation (Arcuolenellus arcuatus-Mexicella mexicana zones; Sundberg and McCollum, 2000; Sundberg, 2011; Webster, 2011a, c; Fig. 2). Its lower part, the Delamar Member, consists of a succession of bioturbated claystone and siltstone interbedded with sandstone and conglomerate layers, with carbonate intercalations at the top (Webster, 2011c). The lower cliff-forming portion of the succeeding Combined Metals Member consists of bioclastic oncolitic limestone, nodular limestone, and thin limestone beds. The upper portion of the Combined Metals Member shows a higher siliciclastic content, represented by ribbon limestone, nodular limestone, siltstone, and sandstone intercalations (Webster, 2011c). The base of the Delamaran starts with the Comet Shale Member (Eokochaspis nodosa-Amecephalus arrojoensis zones; Fig. 2), predominated by claystone and siltstone with a few thin limestone beds (Sundberg and McCollum, 2000; McCollum and McCollum, 2011). It is disconformably overlain by the Susan Duster Limestone Member (Amecephalus arrojoensis-Poliella denticulata zones), which consists of a basal bioclastic limestone, an interval of claystone and nodular limestone, and an upper part of nodular-bedded limestone (Sundberg and McCollum, 2003b; Sundberg, 2011). The overlying Log Cabin Member (Poliella denticulata Zone) consists of claystone and siltstone with intercalations of sandstone and bioclastic limestone (Sundberg and McCollum, 2003b; McCollum and McCollum, 2011; Sundberg, 2011). The uppermost part of the Pioche Formation is represented by the Grassy Spring Member 


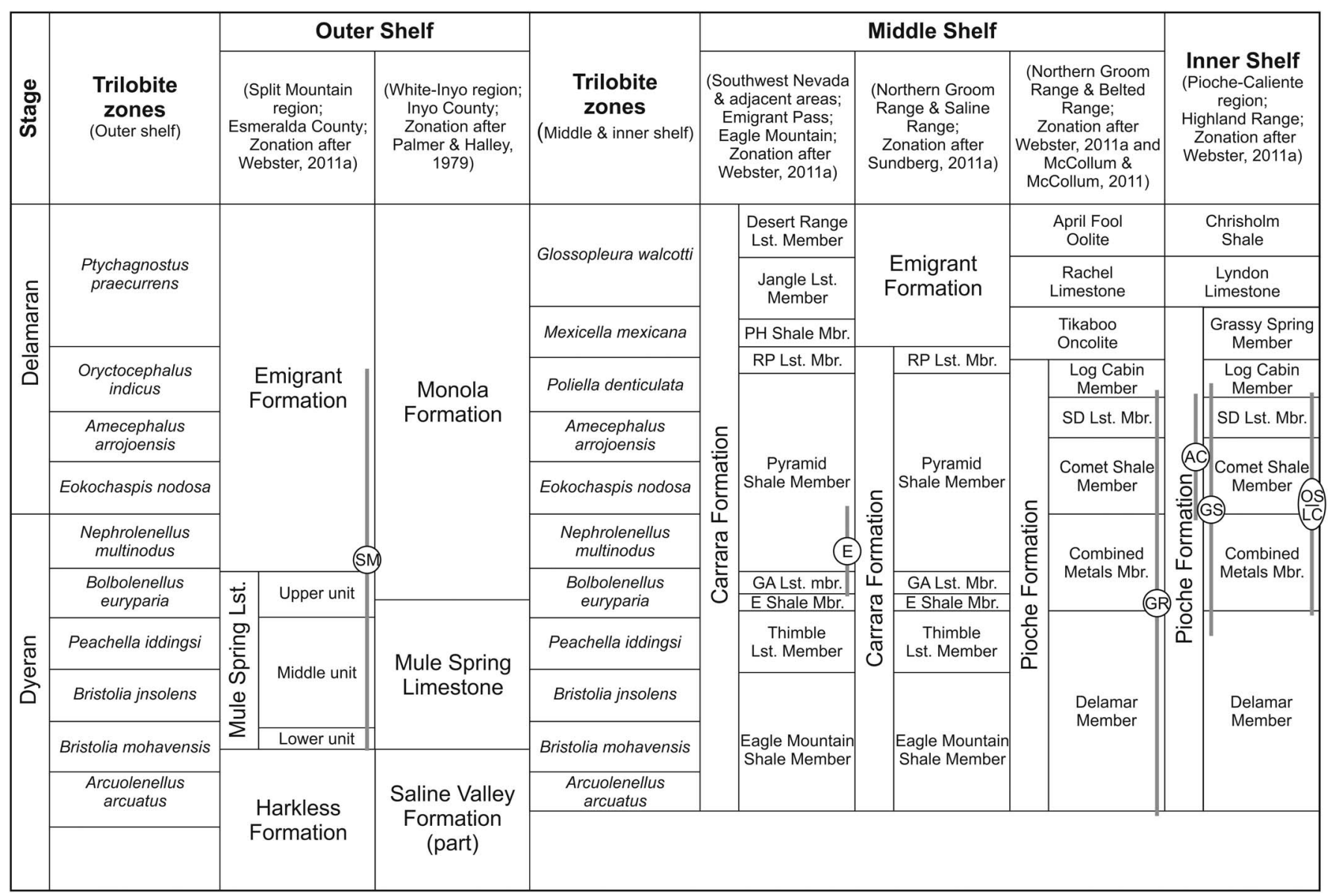

Figure 2. Biostratigraphic zonation of the upper Dyeran-Delamaran interval, and associated lithostratigraphy on the outer, middle, and open shelf of Nevada and SE-California, western Laurentia (modified from Palmer and Halley, 1979; Sundberg and McCollum, 2000, 2003b; McCollum and McCollum, 2011; Sundberg, 2011; Webster, 2011a). Stratigraphic positions of the analyzed Dyeran-Delamaran sections are marked. Abbreviations: E Shale Mbr., Echo Shale Member; GA Lst. Mbr., Gold Ace Limestone Member; PH Shale Mbr., Pahrump Hills Shale Member; RP Lst. Mbr., Red Pass Limestone Member; SD Lst. Mbr., Susan Duster Limestone Member; Lst., limestone; Mbr., member. See Figure 1 for section abbreviations.

(Mexicella mexicana Zone) consisting of claystone, siltstone, and sandstone (Eddy and McCollum, 1998; McCollum and McCollum, 2011; Sundberg, 2011).

Middle shelf facies.-The Dyeran-Delamaran of the middle shelf facies is represented by the Carrara Formation in southern Nevada and southeastern California (Fig. 1). The Carrara Formation is separated into nine siliciclastic and carbonate intervals, ranging from the Arcuolenellus arcuatus Zone to the Glossopleura walcotti Zone (Palmer and Halley, 1979; Webster, 2011a; Fig. 2). The lowermost and uppermost carbonate members (Thimble Limestone and Desert Range Limestone members, respectively) are characterized by thin-bedded argillaceous (dolomitic) limestone (Palmer and Halley, 1979). In contrast, the other limestone portions are cliff-forming units, composed of oncolitic, oolitic, laminated, and fenestral limestone (Palmer and Halley, 1979). The lithostratigraphic nomenclature applied by Palmer and Halley (1979) does not fit with the sedimentary succession observed in the northern Groom Range and Belted Range (GR and BR in Fig. 1) of central Nevada, which resulted in several synonymous nomenclatures for the region (Fig. 2; McCollum and McCollum, 2011; Sundberg, 2011; Webster, 2011a; Webster et al., 2011).
Outer shelf facies.-Sections of the outer shelf facies crop out in western Nevada and eastern California (Fig. 1). The Dyeran Mule Spring Limestone is represented by predominately shallow subtidal-intertidal carbonates and is subdivided into: (1) a lower unit, composed of cliff-forming bioturbated limestone; (2) a middle unit, composed of bioclastic, oncolitic, oolitic, and peloidal limestones with numerous claystone intercalations; and (3) an upper cliff-forming unit composed of oncolitic and fenestral limestones with intercalated intraformational conglomerates (Fig. 2; Nelson, 1962; Stewart, 1970; Albers and Stewart, 1972; Webster, 2011a, b). The Mule Spring Limestone is overlain by the siliciclastic and carbonate, partly highly condensed Emigrant Formation (uppermost Dyeran-Sunwaptan Stage) in western Nevada and by the Monola Formation in Death Valley National Park of eastern California (e.g., Palmer, 1971; Palmer and Halley, 1979; McCollum and McCollum, 2011; Sundberg, 2011; Sundberg et al., 2011). The Monola Formation is subdivided into a lower claystone portion with intercalated limestone and an upper limestone with minor siltstone intercalations (Sundberg and McCollum, 1997). McCollum and McCollum (2011) identified the depositional environment of the Monola Formation as located between the outer shelf position of the Emigrant Formation and the medial to inner shelf positions of the Carrara and Pioche formations. 


\section{Materials and methods}

The material described in this report derives from nine sections covering the Montezuman-Delamaran interval (Terreneuvian/ Cambrian Stage 2-Cambrian Series 3/Cambrian Stage 5) of the different shelf facies realms (Figs. 1-4). All carbonate samples are characterized by a high fossil content observable in thin sections or even macroscopically. However, the major part of small shelly fossils is preserved as carbonate, which hampers extraction from the limestone. Several preparation methods were tested using $95 \%$ to pure acetic acid partly in combination with copper(II) sulfate and chloroform (see Nötzold, 1965; Knitter, 1979; Tarsilli and Warne, 1997). All these methods require a distinct porosity of the limestone that enables the intrusion of chemicals and thus the expansion of the rock due to gassing or crystallization. But, the Laurentian samples are strongly lithified without any porosity, which inhibited extraction of microfossils using these procedures. The best results were realized by dissolving the carbonate samples in buffered $7 \%$ acetic acid. The extracted microfossils are often corroded during the chemical preparation, but it seems to be the only way for releasing a significant number of small shelly fossils from the Laurentian samples. However, due to dissolution of a majority of the carbonate fossils, this procedure delivered only few phosphatic internal molds and silicified specimens out of the total fossil content. Acetic residues were sieved, dried, and the faunal elements were hand-picked from the residue under a binocular microscope. Subsequently, they were mounted, sputter-coated with gold, and photographed under a CamScan 44 scanning electron microscope at the Department of Geology of the University of Cologne.

Repositories and institutional abbreviations.-The material described and figured is housed in the collection of the Geological Institute of the TU Bergakademie Freiberg under the prefix FG 544/GB/locality/sample/SEM-stub number. For brevity herein, localities and specimens are cited without the prefix FG 544/GB. Localities are listed as AC (Antelope Canyon), E (Echo Canyon), GR (Groom Range), GS (Grassy Spring), I (Indian Springs Canyon), LC (Log Cabin Mine), M (Montezuma Range), OS (Oak Spring Summit), and SM (Split Mountain) (Figs. 1-4). Individual collections are denoted by locality abbreviation and sample number (e.g., SM 14).

\section{Systematic paleontology}

The helcionelloid molluscs, Anabarella chelata and Costipelagiella nevadense, were verified from the lowermost Emigrant Formation of the Split Mountain section (SM 14, SM 15; Fig. 3). Stratigraphic position and locality are identical with those published by Skovsted (2006a). Thus, these species are figured (Fig. 5.1-5.16), but not discussed herein.

Phylum Mollusca Cuvier, 1797

Class Helcionelloida Peel, 1991

Order Helcionellida Geyer, 1994

Family Helcionellidae Wenz, 1938

Genus Pelagiella Matthew, 1895
Type species.-Cyrtolithes atlantoides Matthew, 1894; lower Cambrian of southeast New Brunswick, Canada.

Pelagiella aff. P. subangulata (Tate, 1892)

Figures 5.17-5.22, 6.1-6.23, 7.1-7.6, 8.35-8.37

1892 Ophileta subangulata Tate, p. 184, pl. 2, fig. 8a-b.

1984 Pelagiella emeishanensis He in Xing et al., p. 167, pl. 13, figs. 1-5.

1986 Pelagiella sp.; Laurie, p. 447, fig. 10D-E.

1990 Pelagiella subangulata; Runnegar in Bengtson et al., p. 254, figs. 167, 168A-D, 169A-F, H-L.

1994 Pelagiella emeishanensis; Elicki, p. 71, fig. 4.8.

1994 Pelagiella lorenzi Kobayashi, 1939; Elicki, p. 71, fig. 4.6, 4.7.

1996 Pelagiella emeishanensis; Elicki, p. 155, pl. 7, figs. 6, 7.

1996 Pelagiella lorenzi; Elicki, p. 154, pl. 7, figs. 1-5.

1996 ?Pelagiella aff. adunca $\mathrm{He}$ and Pei in $\mathrm{He}, \mathrm{Pei}$, and Fu; Elicki, p. 155, pl. 8, figs. 1-4.

1996 ?Pelagiella sp.; Elicki, p. 156, pl. 8, figs. 5-8.

2001 Pelagiella subangulata; Parkhaev in Gravestock et al., p. 193, pl. 44, figs. 1-14, pl. 45, figs. 1-10.

2002 Pelagiella subangulata; Elicki, p. 23, pl. 1, figs. 1-18.

2003 Pelagiella subangulata; Elicki, p. 57, pl. 2, fig. 1.

2003 Pelagiella subangulata; Elicki, Hamann, and Münzberger, p. 33, pl. 5, figs. 3, 4.

2004 Pelagiella subangulata; Skovsted, p. 30, pl. 8, figs. a, b.

2006 Pelagiella subangulata; Wotte, p. 151, fig. 5.n-5.p.

2007 Pelagiella subangulata; Steiner et al., p. 83, fig. 7I, 7J.

2014 Pelagiella subangulata; Parkhaev, p. 374, pl. 3, figs. $5,6$.

2016 Pelagiella subangulata; Betts et al., p. 183, fig. $18 \mathrm{~A}-18 \mathrm{H}$.

Holotype.—Ophileta subangulata Tate, 1892 (p. 184, pl. 2, fig. 8a, 8b); "Cambrian limestone at Parara, near Ardrossan," South Australia.

Occurrence.-About one hundred internal molds from the Grassy Spring (GS 13), Groom Range (GR 11), Log Cabin Mine (LC 6), Oak Spring Summit (OS 5), and Split Mountain (SM 14) sections; Dyeran Stage. Three internal molds from the Montezuma Range section (M 5); basal Montezuman Stage.

Description.-Small univalve internal molds up to $1 \mathrm{~mm}$ long and $0.4 \mathrm{~mm}$ high. Turbospiral and dextrally coiled with $1-1.5$ rapidly expanding whorls. Last whorl wide; cross section irregular oval/trapezoidal to sub-triangular. Aperture often broken. Near convex right side of the apertural margin the residual of a projecting ear. Spire slightly submerged culminates in a plane or slightly concave left flank. Protoconch often hook-shaped. Surfaces of the molds without ornamentation.

Remarks.-Due to strong corrosion and lack of the aperture in any of the specimens, an affiliation to a definite species of Pelagiella Matthew, 1895 or Costipelagiella Horný, 1964 is difficult. Pelagiella is characterized by a high morphological variation, resulting in a multitude of nominated species, often with unclear differences. Even within a species, variation in 

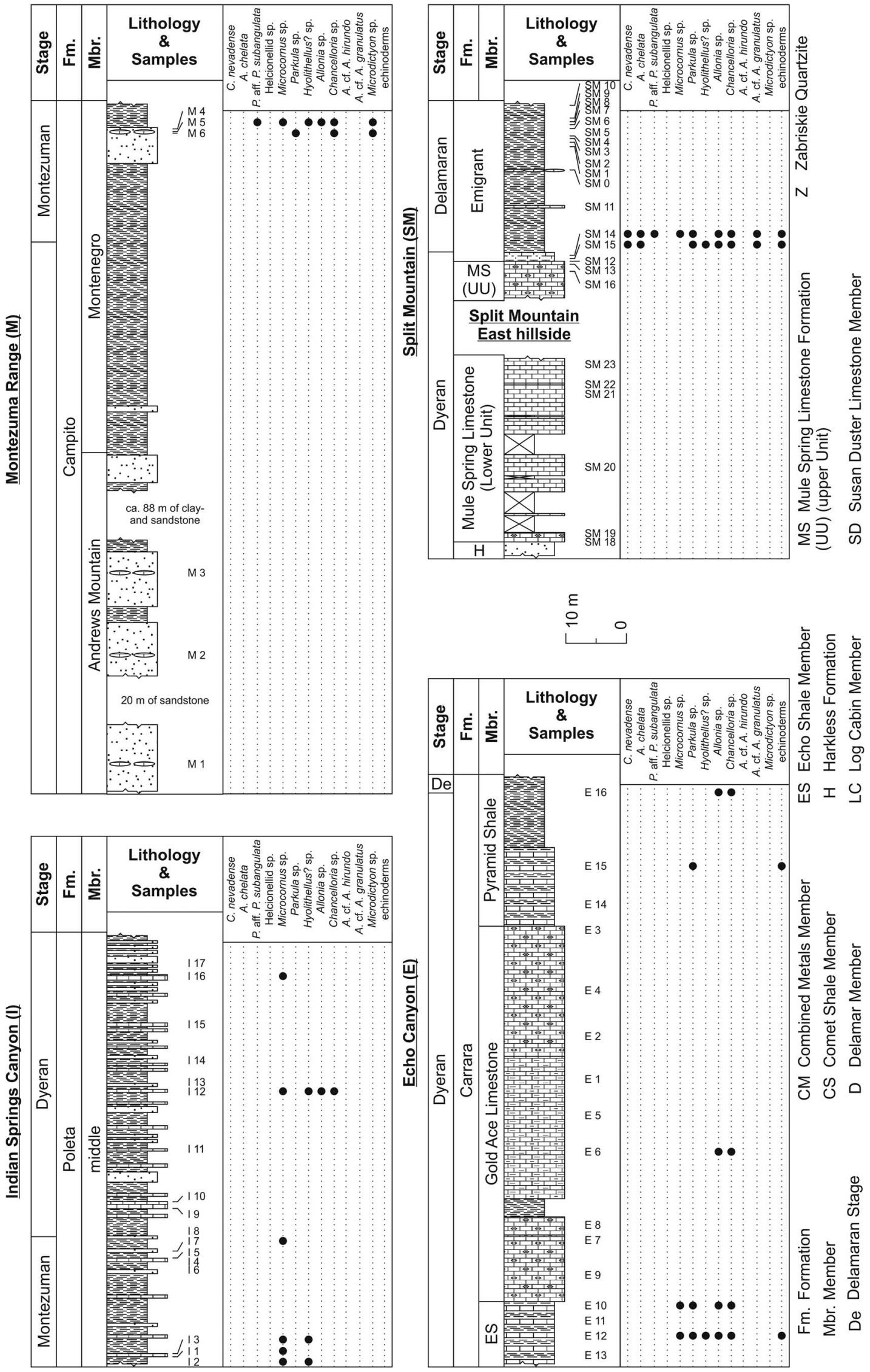

Figure 3. Stratigraphic columns of the studied outer shelf sections with positions of samples investigated. See Figure 4 for legend of lithology. The Fallotaspis Zone corresponds to the illustrated part of the Montezuman Stage. 

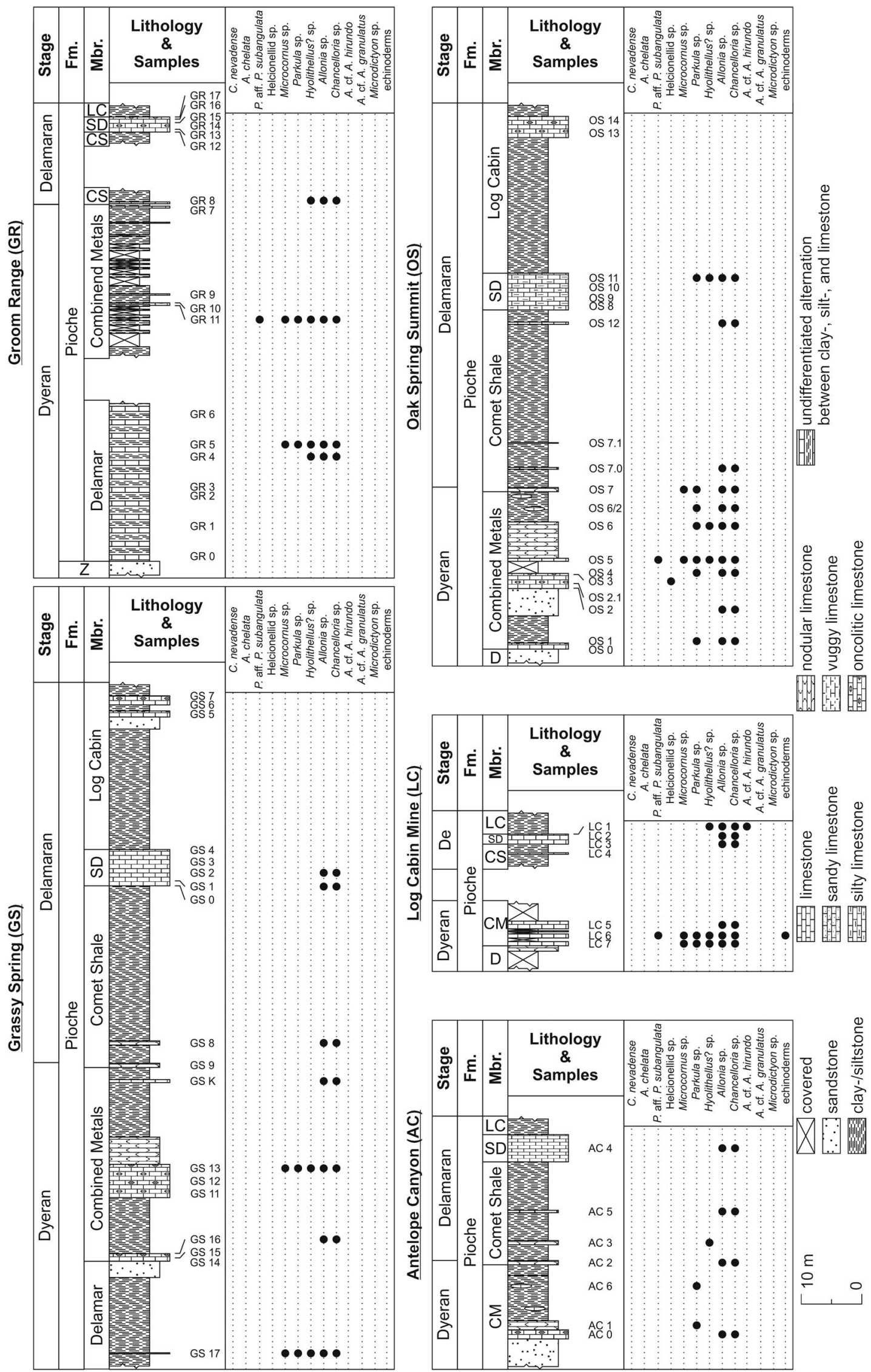

Figure 4. Stratigraphic columns of the studied middle and inner shelf sections with positions of samples investigated. For abbreviations see Figure 3 . 
morphology and ornamentation is large, as it is for $P$. subangulata (Tate, 1892) (Parkhaev in Gravestock et al., 2001; Skovsted, 2004). According to Parkhaev in Gravestock et al. (2001), it is most probable that $P$. subangulata and P. medianensis (Zhou and Xiao, 1984) represent morphologic variations of the same species. However, differences between both species are often only observable from adult forms with well-preserved shell material. According to Parkhaev in Gravestock et al. (2001), P. medianensis is regarded as the junior synonym of $P$. adunca (He and Pei in He et al., 1984), which thus replaces the former species name. On the other hand, it seems that $P$. subangulata continuously shifts morphologically into $P$. adunca, thus suggesting both species represent a morphological continuum within a species. Therefore, $P$. medianensis and $P$. adunca have to be revised, critically. Shell ornamentation of P. subangulata and P. primaeva (Billings, 1872 [1871]) shows comparable V-shaped ridges on the shell periphery (Runnegar in Bengtson et al., 1990; Landing and Bartowski, 1996; Landing et al., 2002). Thus, $P$. primaeva needs a careful revision as well (Skovsted, 2004).

Differences between Pelagiella and Costipelagiella are subtle and only visible on shell morphology and ornamentation. Costipelagiella nevadense Skovsted, 2006a originally derives from the basal Emigrant Formation of the Split Mountain section (Skovsted, 2006a), and occurs in our samples SM 14 and SM 15 as well (Fig. 5.14-5.16). Without preserved shell material, an affiliation of our internal molds to $C$. nevadense could not be excluded with certainty.

Considering the poor preservation of our material and the taxonomic discrepancies mentioned above, we interpret our specimens as having an affinity to $P$. subangulata, characterized by a wide range of variability. However, it should be kept in mind that species identification is questionable when exclusively based on internal molds (Skovsted, 2004; Topper et al., 2009).

Pelagiella subangulata is known from lower and middle Cambrian strata worldwide. Its first occurrence was recently discussed as a potential marker for defining the base of the Cambrian Series2/Stage 3 (e.g., Steiner et al., 2007).

Helcionellid gen. and sp. indet. 1

Figure 7.7-7.12

Occurrence.-Three specimens from the middle part of the Combined Metals Member (Dyeran Stage) of Oak Spring Summit section (OS 3).

Description.-Large, weakly cyrtoconic, cap-shaped shells. Apex blunt and rounded, probably located in a central position; exact position uncertain due to the complete disappearance of the aperture. Ventral cross-section of incomplete specimen OS 3/B2-3 (Fig. 7.7, 7.8) sub-circular to elliptical. Width and length $\sim 1.3 \mathrm{~mm}$ and $\sim 2.6 \mathrm{~mm}$, respectively. More-complete specimens OS 3/B2-4 (Fig. 7.11, 7.12) and OS 3/B2-5 (Fig. 7.9, 7.10) with a long, slightly concave posterior field. Approximate length of these specimens is $2.2 \mathrm{~mm}$ and $1.2 \mathrm{~mm}$, respectively. Maximum height $\sim 1.3 \mathrm{~mm}$. Anterior field gently convex. Surface with distinct radial lirae (Fig. 7.7-7.12).
Remarks.-Specimens show similarities to several helcionelloid molluscs, such as Trenella Parkhaev, 2001, Mellopegma Runnegar and Jell, 1976, Stenotheca Salter in Hicks, 1872, and Helcionella Grabau and Shimer, 1909. The long posterior field of our specimens is similar to Trenella or Mellopegma. According to Parkhaev (2001) the posterior field of T. bifrons Parkhaev, 2001 is rather short and continues into a welldeveloped parietal train. The posterior field of the figured holotype (Parkhaev, 2001, pl. 3, fig. 1a-1c) seems to be more concave than that of our specimens. In addition, the shell of Trenella shows a significant lateral compression without radial lirae and the apex is more spoon-shaped. Species of Mellopegma are characterized by a long, slightly concave posterior field without parietal train. The elongated shell has faint comarginal rugae. The apex is blunt to slightly hooked (see Vendrasco et al., 2011). However, in comparison to our specimens, Mellopegma shows a significant lateral compression. There are also similarities of our material to Stenotheca pojetai Runnegar and Jell, 1976, showing a blunt apex and fine radial lirae. The convexity of the anterior side is similar to that of our material, but the posterior side of $S$. pojetai is more steep and short. Species of Stenotheca are also characterized by a strong lateral compression. A morphological similarity to Helcionella is given by the radial lirae and the oval cross section of the apertural region. Even if species of Helcionella show a wide morphological range (Jacquet and Brock, 2016), the absence of large concentric rugae and a blunter apex in our material make an affiliation to this genus questionable. Considering the subcircular cross-section, similarities to Miroconulus Parkhaev in Gravestock et al. (2001) or Anuliconus Parkhaev in Gravestock et al. (2001) are probable. However, both taxa are characterized by concentric rugae, the apex of Miroconulus is slightly displaced and hooked posteriorly, and Anuliconus is highly conical with a posteriorly hooked apex. Therefore, it seems most probable that our Helcionellid gen. and sp. indet. 1 represents either a new species of Helcionella or a new genus of helcionelloid molluscs. However, the incompleteness of the material hinders a certain taxonomic affiliation.

\section{Helcionellid gen. and sp. indet. 2} Figure 7.13-7.16

Occurrence.-Two specimens from the middle part of the Combined Metals Member (Dyeran Stage) of Oak Spring Summit section (OS 3).

Description.—Large, weakly cyrtoconic, cap-shaped shells with well-developed concentric rugae (Fig. 7.13, 7.15). Apex blunt and rounded; however, specimen OS 3/B2-8 slightly hooked (Fig. 7.13). Aperture is absent, but specimens show a subcircular to elliptical outline. Height and length of the broken specimens OS 3/B2-8 and OS 3/B2-9 are $\sim 0.9 \mathrm{~mm}$ and $\sim 1.9 \mathrm{~mm}$, and $\sim 1.5 \mathrm{~mm}$ and $\sim 2.9 \mathrm{~mm}$, respectively.

Remarks.-Specimens are similar to Helcionellid gen. and sp. indet. 1, but with well-developed concentric rugae and without radial lirae. Rugae, the sub-circular cross-section and the slightly hooked apex indicate an affiliation to Helcionella, but our material shows a blunter apex and the concentric rugae are 


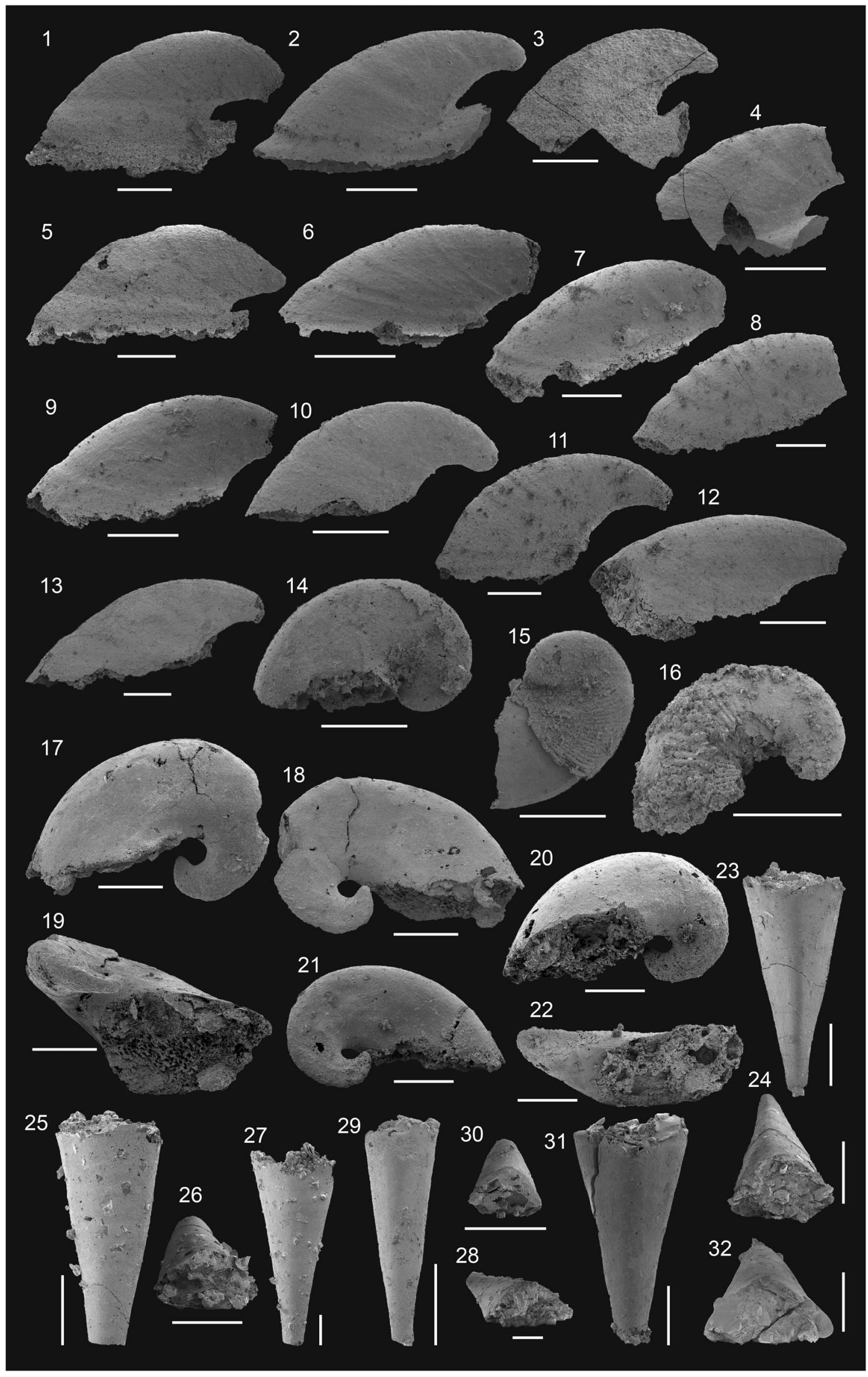


less prominent. Again, poor preservation prevents a secure taxonomic placement.

\author{
Phylum uncertain \\ Class Hyolitha Marek, 1963 \\ Order Hyolithida Sysoiev, 1957 \\ Family Nelegerocornidae Meshkova, 1974 \\ Genus Microcornus Mambetov, 1972
}

Type species.—Microcornus parvulus Mambetov, 1972 (p. 268, fig. 1a-1e); Rhombocorniculum cancellatum Zone, Geres Member, basal Shabakty Formation (lower Cambrian; upper Atdabanian Stage; correlated with the lower Cambrian Stage 3); Ushbas River, Malyi (Lesser) Karatau, Kazakhstan.

Microcornus sp.

Figure 5.23-5.32

Occurrence.-Several poorly preserved internal molds of the Indian Springs Canyon and Montezuma Range sections (I 1, I 2 , I 3, I 7, I 12, I 16, M 5); Montezuman Stage. Several internal molds or shells from the Echo Canyon (E 10, E 12), Grassy Spring (GS 13, GS 17), Groom Range (GR 5, GR 11), Log Cabin Mine (LC 6, LC 7), Oak Spring Summit (OS 5, OS 7), and Split Mountain (SM 14) sections; Dyeran Stage.

Description.-Slender shells or internal molds. Aperture and apex often incomplete. Incomplete specimens normally $\sim 2 \mathrm{~mm}$ long ( $\sim 3.3 \mathrm{~mm}$ maximum; Fig. 5.27). Dorsal side with distinct, rounded median ridge. Ventral side flat to gently convex. Lateral sides rounded. Cross-section sub-triangular. Protoconch absent, but probably separated from the mature conch by a shallow constriction (see Fig. 5.23). Surface sculpture not preserved.

Remarks.-Microcornus differs from Parkula Bengtson in Bengtson et al. (1990) by a more prominent dorsal median ridge and a sub-triangular cross-section. The flat to gently convex ventral side and the sub-triangular cross-section of the conch indicate affiliation to M. eximius Duan, 1984 or M. petilus Bengtson in Bengtson et al., 1990. Microcornus eximius is characterized by a flat ventral side, whereas $M$. petilus has a convex ventral side (Demidenko in Gravestock et al., 2001). However, the absence of opercula prevents an assignment to a species.

\section{Family unassigned}

Genus Parkula Bengtson in Bengtson et al., 1990

Type species.-Parkula bounites Bengtson in Bengtson et al., 1990 (p. 223, figs. 149-151); Abadiella huoi Zone, Parara
Limestone (lower Cambrian; correlated with the Cambrian Series 2); Kulpara, Yorke Peninsula, South Australia.

\author{
Parkula sp. \\ Figure 7.17-7.32
}

Occurrence.-Poorly preserved internal molds from the Montezuma Range section (M 6); Montezuman Stage. Several internal molds or shells from the Antelope Canyon (AC 1, AC 6), Echo Canyon (E 10, E 12, E 15), Grassy Spring (GS 13, GS 17), Groom Range (GR 5, GR 11), Log Cabin Mine (LC 6, LC 7), Oak Spring Summit (OS 1, OS 4, OS 5, OS 6, OS 6/2, OS 7, OS 11), and Split Mountain (SM 14, SM 15) sections; DyeranDelamaran stages.

Description.-Conchs with lenticular cross-section. Dorsal side with faint median ridge. Ventral side less convex than dorsal side. Aperture and apex often incomplete. Most specimens incomplete and $1 \mathrm{~mm}$ in length (with a maximum of $2.7 \mathrm{~mm}$; Fig. 7.21). Angle of divergence 12-20 . Aperture perpendicular to the long axis of the conch. Apex slightly bulbous (Fig. 7.17, 7.19). Surface generally smooth, but a few specimens with faint transverse lines and irregularly spaced depressions of $\sim 6 \mu \mathrm{m}$ in diameter (Fig. 7.19, 7.25).

Remarks.-Parkula differs from Microcornus by having a faint dorsal median ridge and a lenticular to sub-triangular crosssection. Cross-section is similar to P. esmeraldina Skovsted, 2006a. However, poor preservation and the absence of opercula hinder a certain taxonomic affiliation.

$$
\begin{gathered}
\text { Phylum and class uncertain } \\
\text { Order Hyolithelminthida Fisher, } 1962 \\
\text { Family Hyolithellidae Walcott, } 1886 \\
\text { Genus Hyolithellus Billings, } 1872 \text { (1871) }
\end{gathered}
$$

Type species.—Hyolithes micans Billings, 1872 (p. 215, figs. 3a, 3b); Bonnia-Olenellus Zone, Dyeran Stage; Troy, New York State, USA.

\section{Hyolithellus? sp.}

Figure 6.24-6.28

Occurrence.-Several fragments of internal molds from the Montezuma Range (M 5) and Indian Springs Canyon (I 2, I 3) sections; Montezuman Stage. Few fragments from the Echo Canyon section (E 12), Grassy Spring (GS 13, GS 17), Groom Range (GR 4, GR 5, GR 11), Indian Springs Canyon (I 12), Log Cabin Mine (LC 6, LC 7), Oak Spring Summit (OS 5, OS 6), and Split Mountain (SM 15) sections; Dyeran Stage. Several fragments from the Antelope Canyon (AC 3),

\footnotetext{
Figure 5. Molluscs from the Delamar and Combined Metals members of Grassy Spring and Log Cabin Mine sections and from the Emigrant Formation of Split Mountain; Dyeran Stage. (1-13) Anabarella chelata Skovsted, 2006a; scale bar = $200 \mu \mathrm{m}$; lateral views: (1) FG 544/GB/SM/14/A1-17; (2) FG 544/GB/SM/14/A121; (3) FG 544/GB/SM/14/A1-7; (4) FG 544/GB/SM/14/A1-1; (5) FG 544/GB/SM/14/A1-8; (6) FG 544/GB/SM/14/A1-16; (7) FG 544/GB/SM/14/A1-3; (8) FG 544/GB/SM/15/A2-4; (9) FG 544/GB/SM/14/A1-12; (10) FG 544/GB/SM/14/A1-25; (11) FG 544/GB/SM/15/A2-2; (12) FG 544/GB/SM/14/A1-22; (13) FG 544/ GB/SM/15/B8-1. (14-16) Costipelagiella nevadense Skovsted, 2006a; scale bar = $200 \mu \mathrm{m}$; lateral views: (14) FG 544/GB/SM/15/B8-7; (15) FG 544/GB/SM/15/ B8-10; (16) FG 544/GB/SM/14/A1-27. (17-22) Pelagiella aff. P. subangulata (Tate, 1892); scale bar = $200 \mu \mathrm{m}$ : (17-19) FG 544/GB/LC/6/A9-11, (17, 18) lateral view, (19) oblique apertural view; (20-22) FG 544/GB/LC/6/A8-26, (20, 21) lateral view, (22) oblique apertural view. (23-32) Microcornus sp.; scale bar $=500 \mu \mathrm{m}:(\mathbf{2 3}, \mathbf{2 4}) \mathrm{FG} \mathrm{544/GB/GS/17/A4-4,} \mathrm{(23)} \mathrm{dorsal} \mathrm{view,} \mathrm{(24)} \mathrm{oblique} \mathrm{view} \mathrm{from} \mathrm{the} \mathrm{aperture;} \mathrm{(25,} \mathrm{26)} \mathrm{FG} \mathrm{544/GB/GS/17/A4-12,} \mathrm{(25)} \mathrm{dorsal} \mathrm{view,}$ (26) oblique view from the aperture; (27, 28) FG 544/GB/GS/17/A4-10, (27) dorsal view, (28) oblique view from the aperture; (29, 30) FG 544/GB/GS/17/A4-6, (29) dorsal view, (30) oblique view from the aperture; $(\mathbf{3 1}, \mathbf{3 2})$ FG 544/GB/GS/17/A5-16, (31) dorsal view, (32) oblique view from the aperture.
} 


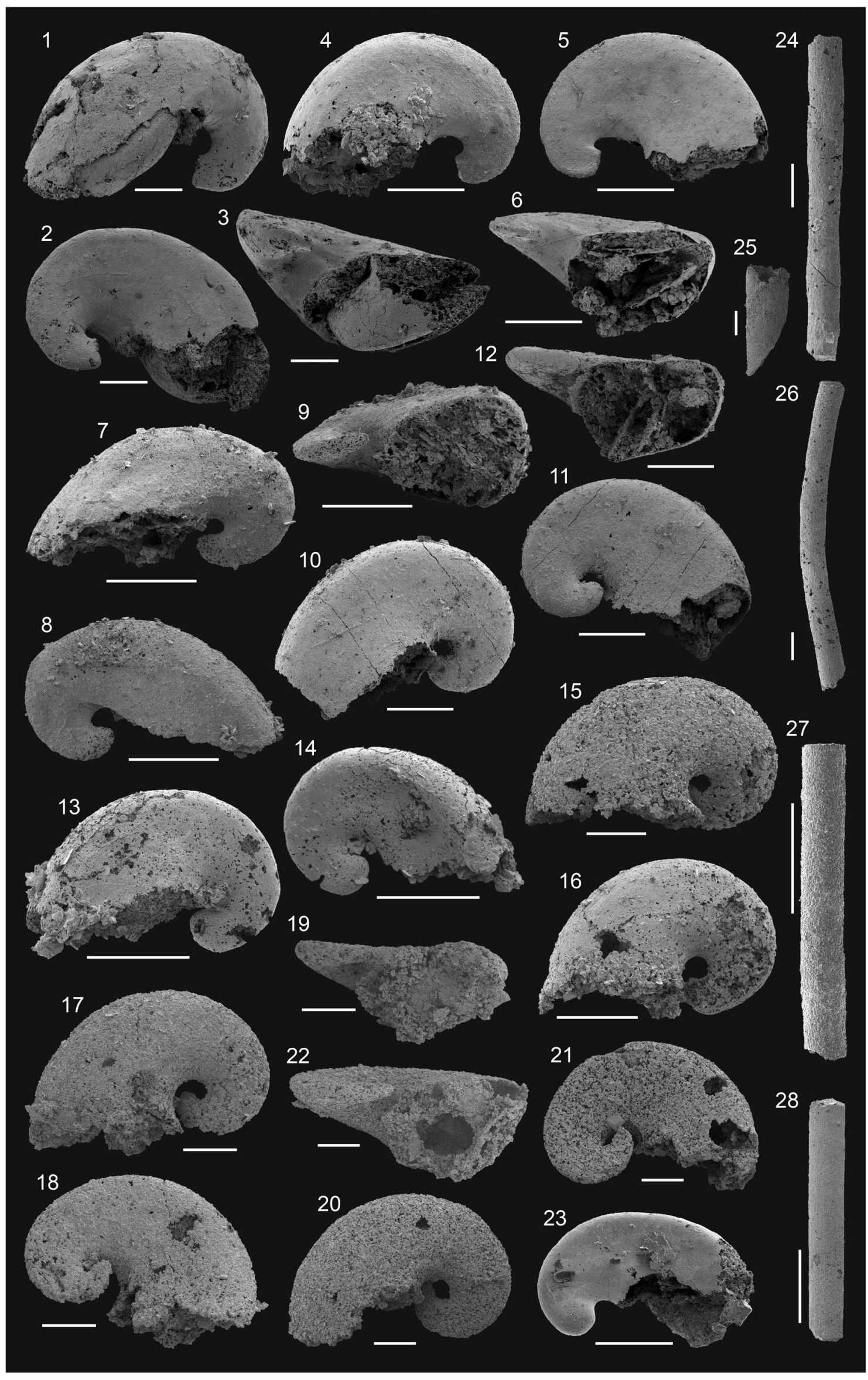


Groom Range (GR 8), Log Cabin Mine (LC 1), and Oak Spring Summit (OS 11) sections; Delamaran Stage.

Description.-Straight (Fig. 6.24, 6.25, 6,27, 6.28) to gently curved (Fig. 6.26) fragments with circular cross-section. Tube fragments slightly expanding. Length and width of tube fragments up to $2.4 \mathrm{~mm}$ and $200 \mu \mathrm{m}$, respectively. Internal molds smooth.

Remarks.-Classification of hyolithelminthids is primarily based on cross-section, ornamentation, and degree of tapering of the phosphatic tubes, which has resulted in a large variety of generic and specific names of often unclear differences (Landing, 1988; Bengtson et al., 1990; Skovsted, 2006b; Paterson et al., 2007; Topper et al., 2009; Skovsted and Peel, 2011; Smith et al., 2015). Following Bengtson in Gravestock et al. (2001) and Elicki (2011), we use the formal classification into hyolithellid and torellellid hyolithelminths. Internal molds described have a circular cross-section and are thus referred with some uncertainty to the hyolithellid genus Hyolithellus Billings, 1872 (1871).

Phylum uncertain

Class Coeloscleritomorpha Bengtson and Missarzhevsky, 1981

Order Chancelloriida Walcott, 1920

Family Chancelloriidae Walcott, 1920

Remarks.-Several samples have produced isolated rays that cannot be assigned to a particular genus within this family. These are listed as chancelloriid spicules even though they may belong to co-occurring taxa listed below.

Genus Allonnia Doré and Reid, 1965

Type species.-Allonnia tripodophora Doré and Reid, 1965 (p. 20, fig. 1); Carteret Formation (lower Cambrian; correlated with the Cambrian Series 2); Carteret, Cotentin Peninsula, Normandy, France.

\section{Allonnia sp. \\ Figure 8.9-8.11}

Occurrence.-Several spicules from the Antelope Canyon (AC 0, AC 2, AC 4, AC 5), Echo Canyon (E 6, E 10, E 12, E 16), Grassy Spring (GS 1, GS 2, GS 8, GS 13, GS 16, GS 17, GS K), Groom Range (GR 4, GR 5, GR 8, GR 11), Indian Springs Canyon (I 12), Log Cabin Mine (LC 1, LC 2, LC 3, LC 5, LC 6, LC 7), Montezuma Range (M 5), Oak Spring Summit (OS 1, OS 2, OS 4, OS 5, OS 6, OS 6/2, OS 7, OS 7.0, OS 11, OS 12), and Split Mountain (SM 14, SM 15) sections; Montezuman-Delamaran stages.
Description.--Poorly preserved spicules with $4+0$ rays slightly diverge from the basal plane.

Remarks.-Chancelloriids with $2+0,3+0$, and $4+0$ rays are referred to the genus Allonnia (see Qian and Bengtson, 1989; Moore et al., 2013). Orientation and arrangement of our fourrayed spicules indicate a systematic affiliation to A. tetrathallis (Jiang in Luo et al., 1982).

\section{Genus Chancelloria Walcott, 1920}

Type species.-Chancelloria eros Walcott, 1920 (p. 329-331, pl. 86, figs. 2, 2a-c; pl. 88, figs. 1, 1a-f); Ogygopsis Zone, Burgess Shale Member, Stephen Formation (middle Cambrian; correlated with the Cambrian Series 3); northeast of Burgess Pass, British Columbia, Canada.

\section{Chancelloria sp. 1}

Figure 8.12-8.15

Occurrence.-Hundreds of spicules from the Log Cabin Mine (LC 6) and Oak Spring Summit (OS 4) sections; Dyeran Stage.

Description.-Poorly preserved spicules with $6+0$ rays. Rays slightly bent upwards from the basal plane. Foramen on the lower side rounded to oval (Fig. 8.14).

Remarks.-Detailed systematic affiliation is difficult due to poor preservation. Shape and organization of spicules suggest an affiliation to Chancelloria. However, an affiliation to Archiasterella Sdzuy, 1969 (e.g., A. elegans Demidenko in Gravestock et al., 2001) could not be excluded.

Chancelloria sp. 2

Figure 8.16-8.22

Occurrence.-Thousands of spicules and large number of isolated rays from the Antelope Canyon (AC 0, AC 2, AC 4, AC 5), Echo Canyon (E 6, E 10, E 12, E 16), Grassy Spring (GS 1, GS 2, GS 8, GS 13, GS 16, GS 17, GS K), Groom Range (GR 4, GR 5, GR 8, GR 11), Indian Springs Canyon (I 12), Log Cabin Mine (LC 1, LC 2, LC 3, LC 5, LC 6, LC 7), Montezuma Range (M 5, M 6), Oak Spring Summit (OS 1, OS 2, OS 4, OS 5 , OS 6, OS 6/2, OS 7, OS 7.0, OS 11, OS 12), and Split Mountain sections (SM 14, SM 15); Montezuman-Delamaran stages.

Description.-Spicules with $5+1$ broken rays. The vertical ray is more robust and shorter than the lateral rays. Rays slightly bent upwards from the basal plane.

Figure 6. Small shelly fossils from the Campito, Delamar, Echo Shale, Combined Metals members of Montezuma Range, Echo Canyon, Grassy Spring, Oak Spring Summit, Log Cabin Mine sections as well as from the basal Emigrant Formation of Split Mountain; Montezuman-Dyeran stages; all scale bars $200 \mu$ m: (1-23) Pelagiella aff. P. subangulata (Tate, 1892): (1-3) FG 544/GB/LC/6/A9-12, (1, 2) lateral view, (3) oblique apertural view; (4-6) FG 544/GB/LC/6/A9-19, $(\mathbf{4 , 5})$ lateral view, (6) oblique apertural view; (7-9) FG 544/GB/LC/6/A9-33, (7, 8) lateral view, (9) oblique apertural view; (10-12) FG 544/GB/SM/14/A1-13, $(\mathbf{1 0}, \mathbf{1 1})$ lateral view, colonization of endolithic cyanobacteria on the internal mold, (12) oblique apertural view; (13, 14) FG 544/GB/OS/5/A12-13, lateral view; (15) FG 544/GB/GR/11/A10-11, lateral view; (16) FG 544/GB/GR/11/A10-22, lateral view; (17-19) FG 544/GB/GR/11/A10-6, (17, 18) lateral view, (19) oblique apertural view; $(\mathbf{2 0 - 2 2})$ FG 544/GB/GR/11/A10-31, $(\mathbf{2 0}, \mathbf{2 1})$ lateral view, (22) oblique apertural view; $(\mathbf{2 3}) \mathrm{FG} 544 / \mathrm{GB} / \mathrm{GS} / 13 / \mathrm{A} 6-14$, oblique lateral view. (24-28) Hyolithellus? sp.: (24) FG 544/GB/M/5/C8-2; (25) FG 544/GB/LC/6/A8-1; (26) FG 544/GB/M/5/C8-1; (27) FG 544/GB/M/5/C8-3; (28) FG 544/GB/GS/17/A5-11. 


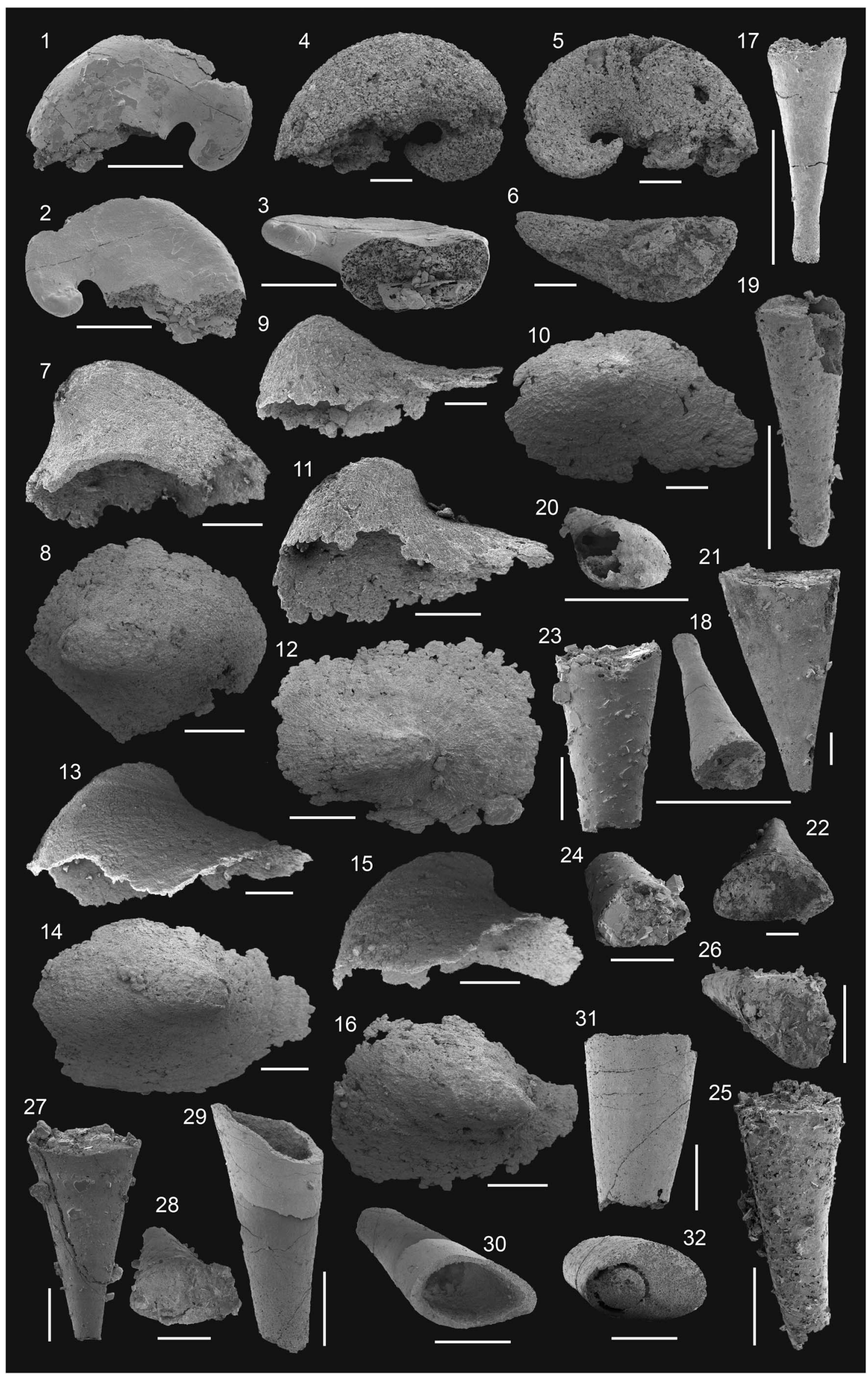


Remarks.-Spicules show a flat base and an almost radial symmetry. Number and arrangement of the rays indicates a systematic affiliation to Chancelloria.

Genus Archiasterella Sdzuy, 1969

Type species.-Archiasterella pentactina Sdzuy, 1969 (p. 134-137, pl. 15, fig. 4-12, 13?, text figs. 2d, 3, 4); Andalusiana cornuta-Termierella sevillana band (lower Cambrian; middle Marianian Stage; correlated with the uppermost Terreneuvuian/Cambrian Stage 2); basin of Guadalcanal, Sierra Morena, southern Spain.

Archiasterella cf. A. hirundo Bengtson in Bengtson et al., 1990 Figure 8.23

Occurrence.-One spicule from the Log Cabin Mine section (LC 1); Delamaran Stage.

Description.-Spicule with $4+0$ rays. Specimen strongly recrystallized.

Remarks.-Configuration and arrangement of rays suggests a similarity with A. hirundo Bengtson in Bengtson et al., 1990.

Phylum Echinodermata Klein, 1734

Indeterminate echinoderm ossicles Figure 8.1-8.8

Occurrence.-Several ossicles from the Echo Canyon (E 12, E 15), Log Cabin Mine (LC 6), and Split Mountain (SM 14, SM 15) sections; Dyeran Stage.

Remarks.-Echinoderm ossicles with preserved stereome microstructure. Morphology ranges from plates, irregular segments, to barrel-shaped segments, typical for eocrinoids and edrioasteroids. However, no assignment to a particular taxon is possible.

Phylum Tardipolypoda Chen and Zhou, 1997

Class Xenusia Dzik and Krumbiegel, 1989

Order Scleronychophora Hou and Bergström, 1995

Family Eoconchariidae Hao and Shu, 1987

Genus Microdictyon Bengtson, Matthews, and Missarzhevsky in Missarzhevsky and Mambetov, 1981

Type species.-Microdictyon effusum Bengtson, Matthews, and Missarzhevsky in Missarzhevsky and Mambetov, 1981 (p. 78, pl. 13, figs. 3, 5); Rhombocorniculum cancellatum Zone, Geres Member, basal Shabakty Formation (lower Cambrian; upper
Atdabanian Stage; correlated with the lower Cambrian Series 2); Ushbas River, Malyi (Lesser) Karatau, Kazakhstan (see Mambetov and Missarzhevsky, 1972).

\section{Microdictyon montezumaensis new species}

Figure 8.24-8.25

Holotype.-Specimen FG 544/GB/M/5/C8-8 from sample M 5 from the upper Fallotaspis Zone of the Montenegro Member; middle Montezuman Stage; $5 \mathrm{~m}$ below the $127 \mathrm{~m}$ aluminum tag; Montezuma Range section.

Diagnosis.—Microdictyon with simple, smooth nodes.

Description.—One fragment of $\sim 180 \mu \mathrm{m}$ thickness (Fig. 8.25). Sclerite composed of a dense crystalline layer (capping, sensu Bengtson et al., 1986) forming its surface and the walls/bases of holes, and a coarser crystalline layer hosting the holes (framework, sensu Bengtson et al., 1986). Holes surrounded by a prominent ridge (Fig. 8.24, 8.25). Cross-section of holes clearly shows the relationship between holes and ridges, offering a barrel-shaped structure (Fig. 8.25). At the capping, hole diameters constricting from $\sim 80 \mu \mathrm{m}$ to $\sim 50 \mu \mathrm{m}$, extending into bulbous cavities (width of $120 \mu \mathrm{m}$ in their central part) in the framework. Holes surrounded by six regularly arranged weak nodes (Fig. 8.24, 8.25).

Etymology.—Named after Montezuma Range.

Remarks.-The exact determination of Microdictyon species is primarily based on the morphology of the nodes surrounding the holes. A further aspect is the hole diameter and a common basal closure of the holes. The last feature is a typical characteristic of M. effusum (Bengtson et al., 1986, p. 101, fig. 3). However, the absence of such a basal closure in all other described species of Microdictyon may be an artifact of preservation. According to the original description, the nodes of M. effusum have a mushroomlike shape, although this and the basal closure are not observable on the figured material (Bengtson et al. in Missarzhevsky and Mambetov, 1981, pl. 13, figs. 3, 5). Bengtson et al. (1986) described a distinct brim and a sub-centrally placed apex for M. effusum. Nodes of our sclerite show no prominent relief (Fig. 8.24, 8.25). However, the good preservation of the surface layer indicates no or only minor erosion, thus excluding a destruction of prominent nodes. Therefore, the gentle morphology on the sclerite is considered as representing the original shape. Because the structure of the nodes is an essential criterion for species definition, it is necessary to assign this fragment to the new species M. montezumaensis.

\footnotetext{
Figure 7. Small shelly fossils from the Delamar, Echo Shale, and Combined Metals members of Echo Canyon, Grassy Spring, Groom Range, and Oak Spring Summit sections; Dyeran Stage. (1-6) Pelagiella aff. P. subangulata (Tate, 1892); scale bar $=200 \mu \mathrm{m:}$ (1-3) FG 544/GB/GS/13/A6-8, (1, 2) lateral view, (3) oblique apertural view; (4-6) FG 544/GB/GR/11/A10-14, $(\mathbf{4}, \mathbf{5})$ lateral view, (6) oblique apertural view. (7-12) Helcionellid gen. and sp. indet. 1; note the fine radial lirae in the apical region: $(\mathbf{7 , 8}) \mathrm{FG} 544 / \mathrm{GB} / \mathrm{OS} / 3 / \mathrm{B} 2-3$; scale bar $=500 \mu \mathrm{m}$; (7) lateral view, (8) apical view; $(\mathbf{9}, \mathbf{1 0}) \mathrm{FG} 544 / \mathrm{GB} / \mathrm{OS} / 3 / \mathrm{B} 2-5$; scale bar $=200 \mu \mathrm{m} ;(\mathbf{9})$ lateral view, (10) apical view; $(\mathbf{1 1}, \mathbf{1 2}) \mathrm{FG} 544 / \mathrm{GB} / \mathrm{OS} / 3 / \mathrm{B} 2-4$; scale bar $=500 \mu \mathrm{m}$; (11) lateral view, (12) apical view. (13-16) Helcionellid gen. and sp. indet. 2; scale bar $=500 \mu \mathrm{m}$; note the well-developed concentric rugae in the apical region: $(\mathbf{1 3}, \mathbf{1 4}) \mathrm{FG} 544 / \mathrm{GB} / \mathrm{OS} / 3 / \mathrm{B} 2-8$, (13) lateral view, (14) apical view; (15, 16) FG 544/ GB/OS/3/B2-9, (15) lateral view, (16) apical view. (17-32) Parkula sp.; scale bars $400 \mu \mathrm{m}$ except for $(\mathbf{2 5}, \mathbf{2 6}, \mathbf{3 1}, \mathbf{3 2})(200 \mu \mathrm{m}):(\mathbf{1 7}, \mathbf{1 8}) \mathrm{FG} 544 / \mathrm{GB} / \mathrm{GS} / 13 / \mathrm{A6}-2$, (17) dorsal view, (18) oblique view from the aperture; (19, 20) FG 544/GB/E/12/B6-17, (19) dorsal view, (20) oblique view from the aperture; (21, 22) FG 544/GB/ GS/17/A4-14, (21) dorsal view, (22) oblique view from the aperture; (23, 24) FG 544/GB/GS/17/A5-15, (23) dorsal view, (24) oblique view from the aperture; $(\mathbf{2 5}, \mathbf{2 6})$ FG 544/GB/E/12/B6-7, (25) dorsal view, (26) oblique view from the aperture; (27, 28) FG 544/GB/GS/17/A5-16, (27) dorsal view, (28) oblique view from the aperture; (29, 30) FG 544/GB/E/10/A3-5, (29) dorsal view, (30) oblique view from the aperture; (31, 32) FG 544/GB/E/10/A3-2, (31) dorsal view, (32) oblique view from the aperture.
} 


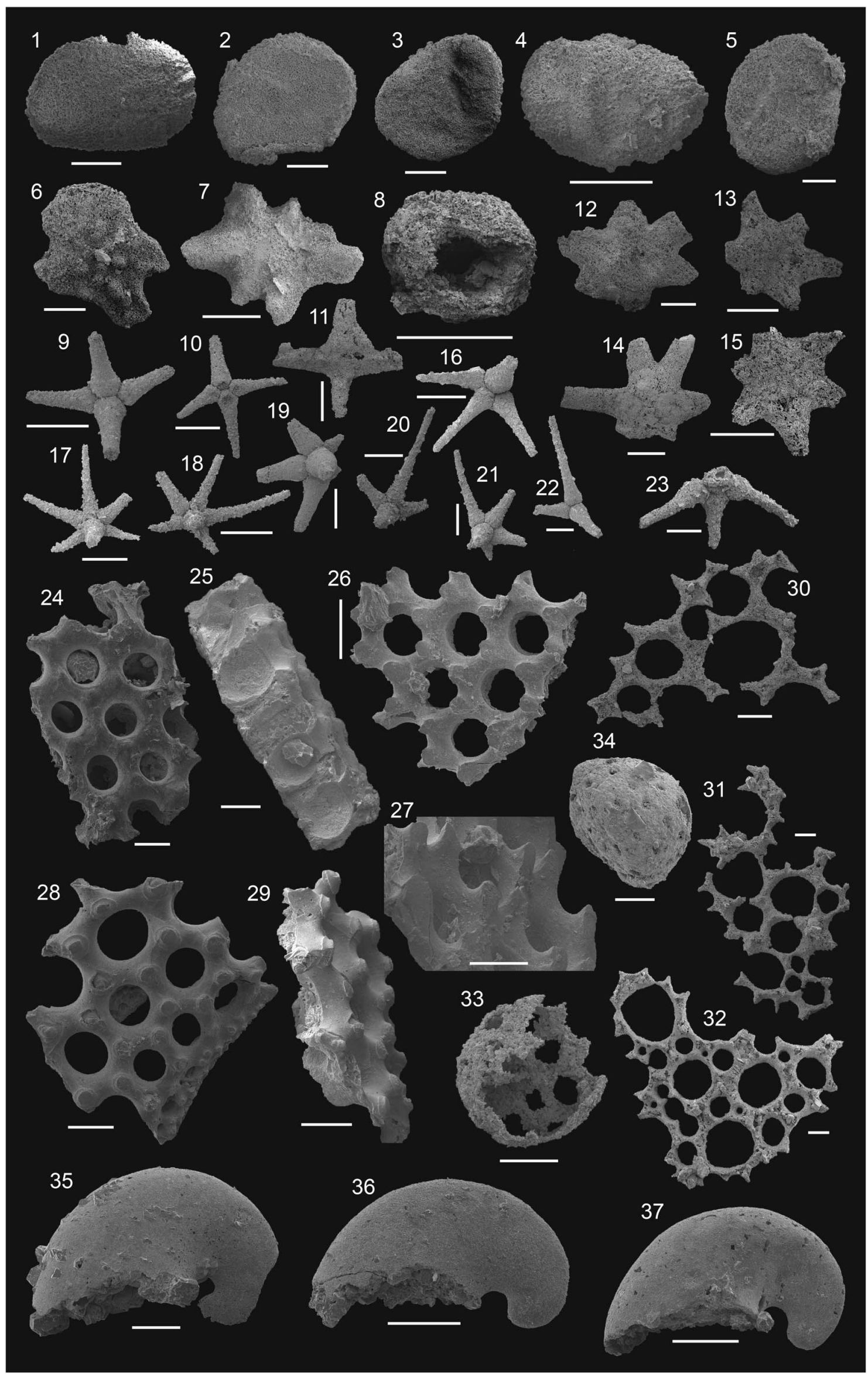


It should be kept in mind that individual complete plates of Microdictyon could combine features (e.g., node morphology) diagnostic for a range of species (Chen et al., 1989; Topper et al., 2011). The simple, hump-like nodes of Microdictyon montezumaensis n. sp. are singular for this species and not known from other fragments and complete plates of Microdictyon. However, it couldn't be excluded that the generally applied diagnostic characteristics result in a multitude of different species of Microdictyon, probably overestimating the real taxonomic diversity, and thus have to be critically revised.

Most Microdictyon sclerites are found in lower Cambrian successions worldwide. Few specimens are known from the middle Cambrian (Ptychagnostus gibbus Zone) of Utah and Bornholm, both probably representing reworked lower Cambrian material (Bengtson et al., 1986; Berg-Madsen, 1981).

\section{Microdictyon cuneum new species}

Figure 8.26, 8.27

Holotype.-Fragmented specimen FG 544/GB/M/5/C8-17 from sample M 5 from the upper Fallotaspis Zone of the Montenegro Member; middle Montezuman Stage; $5 \mathrm{~m}$ below the $127 \mathrm{~m}$ aluminum tag; Montezuma Range section.

Diagnosis.—Microdictyon with short, wedge-shaped nodes.

Description.-Fragment with fully preserved, dense crystalline capping and partly preserved, coarse crystalline framework. Thickness $\sim 50 \mu \mathrm{m}$. Hole diameter nearly uniform, $\sim 75 \mu \mathrm{m}$. Nodes wedge shaped, gradually develop from ridges that surround the holes. One side of the nodes forms an angle of $\sim 30^{\circ}$ with the ridge surface forming the wedge shape. Other side of nodes forms an overhang or an acute angle to the ridge. Wedgeshaped nodes are oriented into the same direction.

Etymology.-Latin cuneus, meaning wedge. Referring to the wedge-shaped appearance of the nodes.

Remarks.-Only two species of Microdictyon are characterized by spike-shaped nodes: Microdictyon robisoni Bengtson, Matthews, and Missarzhevsky, 1986 shows tall and narrow nodes ending in slight expansions. These expansions are clearly offset from the basal socket, which is not present in our specimen. Nodes of M. sphaeroides Hinz, 1987 develop from a smaller base to a wide, flat rim, finally culminating in a sloped spine. Therefore, node morphology of both species is completely different compared to $M$. cuneum $\mathrm{n}$. sp. Nodes of
M. cuneum n. sp. develop continuously from the rim of the capping showing no offset or rim. They are also shorter than the spiny nodes of $M$. robisoni.

\author{
Microdictyon rhomboidale Bengtson, Matthews, and \\ Missarzhevsky, 1986 \\ Figure 8.28, 8.29
}

1986 Microdictyon rhomboidale Bengtson, Matthews, and Missarzhevsky, p. 102, figs. 4-6.

1987 Microdictyon sp.; Voronova et al., p. 56, pl. 24, figs. 6-7. 1992 Microdictyon rhomboidale; Bengtson and Conway Morris, p. 461, fig. 2F.

2007 Microdictyon aff. rhomboidale; Zhang and Aldridge, p. 405 , fig. $2 \mathrm{~N}-2 \mathrm{R}$.

2013 Microdictyon rhomboidale; Bengtson and Conway Morris, p. 461, fig. 2F.

2015 Microdictyon cf. rhomboidale; Kouchinsky et al., p. 481, fig. 55.

2015 Microdictyon sp.; Kouchinsky et al., p. 481, fig. 56.

Holotype.-Microdictyon rhomboidale Bengtson et al., 1986 (figs. 4-6); lower Cambrian (upper Atdabanian or lower Botoman stages; correlated with the middle to upper Cambrian Stage 3); north of Bograd village, Batney Hills, Kuznetskij Alatau Range, Republic of Khakassia, Russia (see Zadorozhnaya et al., 1973).

Occurrence.-One fragment from sample M 5 from the upper Fallotaspis Zone of the Montenegro Member; middle Montezuman Stage; $5 \mathrm{~m}$ below the $127 \mathrm{~m}$ aluminum tag; Montezuma Range section.

Description.-Holes are circular to sub-circular, decreasing in size towards the rim, range of $115 \mu \mathrm{m}$ to $14 \mu \mathrm{m}$ near margin. Nodes slightly mushroom-shaped with distinct brim.

Remarks.-The capping of the fragment is completely preserved, whereas the major part of the framework is corroded. The fragment represents the periphery of a complete sclerite with a steep rim (Fig. 8.28). The shape of the nodes is typical for M. rhomboidale Bengtson et al., 1986. The fragment compares well to Microdictyon n. sp. 1 of Bengtson et al. (1986) described from the region $42 \mathrm{~km}$ south of Goldfield (Esmeralda County, Nevada; Albers and Stewart, 1972). The material is derived from the lower Nevadella Zone and is thus stratigraphically slightly younger than the fragments described herein. According

Figure 8. Small shelly fossils from the Echo Shale, Pyramid Shale, Combined Metals, and Comet Shale members of the Montezuma Range, Oak Spring Summit, and Log Cabin Mine sections, as well as from the basal Emigrant Formation of Split Mountain; Montezuman-Delamaran stages. (1-8) indeterminate echinoderm ossicles; scale bar = 400 $\mu \mathrm{m}$ : (1) FG 544/GB/E/12/B1-2; (2) FG 544/GB/E/15/B4-9; (3) FG 544/GB/E/15/B4-5; (4) FG 544/GB/E/12/B1-1; (5) FG 544/GB/E/15/ B4-10; (6) FG 544/GB/E/16/B4-2; (7) FG 544/GB/SM/15/B8-5; (8) FG 544/GB/E/12/B1-6. (9-11) Allonnia sp.; scale bar = 400 $\mu$ m: (9) FG 544/GB/OS/7/C11-13; (10) FG 544/GB/OS/7/C11-22; (11) FG 544/GB/OS/4/C2-13. (12-15) Chancelloria sp. 1; scale bar = 400 $\mu \mathrm{m}$ except (14) (700 $\mu \mathrm{m})$ : (12) FG 544/GB/LC/6/A8-3; (13) FG 544/GB/LC/6/A8-4; (14) FG 544/GB/OS/4/C2-12; (15) FG 544/GB/LC/6/A8-5. (16-22) Chancelloria sp. 2; scale bar = 300 $\mu$ m: (16) FG 544/GB/OS/7/ C11-11; (17) FG 544/GB/OS/7/C11-12; (18) FG 544/GB/OS/7/C11-10; (19) FG 544/GB/OS/7/C11-21; (20) FG 544/GB/OS/7/C11-18; (21) FG 544/GB/OS/7/C1115; (22) FG 544/GB/OS/7/C11-4. (23) Archiasterella cf. A. hirundo Bengtson in Bengtson et al., 1990; FG 544/GB/LC/1/B3-7; scale bar 300 $\mu$ m. (24, 25) Holotype of Microdictyon montezumaensis n. sp.; FG 544/GB/M/5/C8-8; scale bar = $100 \mu \mathrm{m}$ : (24) ventral view, (25) lateral view of (24). (26, 27) Holotype of Microdictyon cuneum n. sp.; FG 544/GB/M/5/C8-17: (26) ventral view; scale bar $100 \mu \mathrm{m}$, (27) detail of (26); scale bar 50 $\mu \mathrm{m}$. (28, 29) Microdictyon rhomboidale Bengtson et al., 1986; scale bar = $100 \mu \mathrm{m}$ : (28) FG 544/GB/M/5/C8-9, (29) oblique lateral view of (28). (30-32) Microdictyon sp.; scale bar = 100 $\mu \mathrm{m}$ : (30) ventral view; FG 544/ GB/M/5/C6-8; (31) ventral view; FG 544/GB/M/6/B10-3; (32) ventral view; FG 544/GB/M/6/B10-2. (33, 34) Archaeooides cf. A. granulatus Qian, 1977; scale bar $=100 \mu \mathrm{m}:(33)$ FG 544/GB/SM/15/B8-20; (34) FG 544/GB/SM/14/A1-5. (35-37) Pelagiella aff. P. subangulata $($ Tate, 1892); scale bar = 200 $\mu$ m: (35) FG 544/GB/M/5/C8-13, lateral view; (36) FG 544/GB/M/5/C8-12, lateral view; (37) FG 544/GB/M/5/C8-11, lateral view. 
to Bengtson et al. (1986) their Nevadan material could be most probably referred to $M$. cf. rhomboidale. Due to the stratigraphic and regional closeness of both settings, an affiliation of our fragment to $M$. rhomboidale is most probable.

\section{Microdictyon sp.}

Figure 8.30-8.32

Occurrence.-Several fragments from samples M 5 and M 6 from the upper Fallotaspis Zone of the Montenegro Member; middle Montezuman Stage; M 5 and M6 are located $5 \mathrm{~m}$ and $6 \mathrm{~m}$, respectively, below the $127 \mathrm{~m}$ aluminum tag; Montezuma Range section.

Description.-Thin phosphatic plate fragments with hexagonal meshwork. The plates represent only the upper capping. Hole diameter ranges from $85 \mu \mathrm{m}$ and $180 \mu \mathrm{m}$ on the slightly convex surface and decreases to $<9 \mu \mathrm{m}$ towards the periphery. Fragments strongly corroded, obliterating any prominent surface and probably enlarging hole diameters.

Remarks.-Due to the insufficient preservation of our fragments no exact determination is possible.

$$
\text { Genus Archaeooides Qian, } 1977
$$

Type species.-Archaeooides granulatus Qian, 1977 (pl. 2, fig. 21); Meishucunian Stage (correlated with the Cambrian Stage 2); central and southwest China.

\section{Archaeooides cf. A. granulatus Qian, 1977}

Figure 8.33, 8.34

Occurrence.-Two specimens from samples SM 14 and SM 15 from the lowermost Emigrant Formation of the Split Mountain section; Samples SM 14 and SM 15 are derived $1.0 \mathrm{~m}$ respectively $0.5 \mathrm{~m}$ above the base of the Emigrant Formation; Dyeran Stage.

Description.-Well-rounded to flattened on one side, hollow, ranging from $250 \mu \mathrm{m}$ (Fig. 8.33) to $365 \mu \mathrm{m}$ (Fig. 8.34) in diameter. Surface with crystalline texture and covered with circular to oval pits $15-23 \mu \mathrm{m}$ in diameter.

Remarks.-The spherical specimen from sample SM 15 (Fig. 8.33 ) is similar to the 'perforated sphere' published by Skovsted (2006a, fig. 4C) from the same locality but from a slightly higher stratigraphic position ( 1.4 $\mathrm{m}$ above the base of the Emigrant Formation). The absence of a flattened area suggesting an encrusting lifestyle of the organism excludes an affiliation of both spheres to Aetholicopalla Conway-Morris in Bengtson et al., 1990. There is also no indication for a double-walled surface, even if an erosion of the outer wall could not be excluded. The spheres show clear similarities to Archaeooides granulatus Qian, 1977, which are single-walled. The surface of A. granulatus and related synonyms (e.g., A. kuanchuanpuensis Qian, 1977, A. acuspinatus Qian, 1977, Gaparella porosa Missarzhevsky in Missarzhevsky and Mambetov, 1981) is characterized by porous tubercles with pore diameters ranging from $10 \mu \mathrm{m}$ to $30 \mu \mathrm{m}$ (Missarzhevsky and Mambetov, 1981; Missarzhevsky, 1989; Parkhaev and Demidenko, 2010). Surface ornamentations of the specimen of sample SM 15 and that figured by Skovsted (2006a) are probably corroded.

The specimen of sample SM 14 (Fig. 8.34) shows a slightly convex area, which could be interpreted as a zone of attachment of the organism on the substrate, typical for Aetolicopalla granulata Conway Morris in Bengtson et al., 1990. However, the occurrence of pores, even on this area, points against an encrusting life mode of the hemisphere. There is further no indication for a double-wall that necessary for defining this subsphere to Aetolicopalla. The porous structure of the surface indicates an association to Archaeooides granultus, even if a prominent sculpture/ornamentation does not occur. Archaeooides granulatus is characterized by a wide morphology, ranging from spheres, ellipsoids, and hemispheres to spheres flattened on two opposite sides (see Parkhaev and Demidenko, 2010). The specimen of sample SM 15 fits into this morphological range. The pores of the Laurentian specimens are fewer than known from Archaeooides. However, based on their (hemi)spheroidal morphology and the single wall, the Laurentian organisms from samples SM 14 and SM 15 and the specimen of Skovsted (2006a) are referred to Archaeooides cf. A. granulatus Qian, 1977.

The general stratigraphic occurrence of Archaeooides and Aetholicopalla is the Tommotian-Botoman interval of the Siberian nomenclature, which is the Meishucunian-Nangaoan stages of the Chinese nomenclature. The record of the Laurentian Archaeooides slightly below the DyeranDelamaran boundary most probably represents the youngest occurrence of these organisms worldwide.

\section{Discussion}

Fossil distribution patterns are most probably an artifact of the chemical preparation that eliminated portions of the calcareous microfossils. Helcionelloid molluscs, hyoliths, and hyolithelminths occur in almost all sections investigated for the inner, middle, and outer shelf environments of Nevada and California. Sclerites of sponges and chancelloriids are almost absent at Grassy Spring section (inner shelf), whereas echinoderm ossicles only occur at Split Mountain (outer shelf), Echo Canyon, and Log Cabin Mine sections (both inner shelf; Figs. 3, 4).

Occurrences of Pelagiella aff. P. subangulata and several species of Microdictyon in the lower part of the Montezuman Stage in the Montezuman Range section are most probably important for biostratigraphic correlation. Taxa such as Pelagiella subangulata, Microdictyon effusum, and the tooth-like sclerite Rhombocorniculum cancellatum (Cobbold, 1921) are characterized by an almost worldwide distribution and are thus useful for correlation of Cambrian Series 2/Stage 3 (Li et al., 2003; Steiner et al., 2007; Rozanov et al., 2008). Well-established biozonations based on SSF assemblages including these taxa were used in Siberia (the so-called Tommotian fauna; e.g., Khomentovsky and Karlova, 1993), Australia (e.g., Gravestock et al., 2001; Jago et al., 2002, 2006), and South China (e.g., Qian, 1999). Steiner et al. (2007) using the $P$. subangulata and the $R$. cancellatum taxon-range zones for the base of Cambrian Series 2 have provided detailed correlation between several regions of the 
Yangtze Platform. Both zones contain additional important faunal elements (e.g., M. effusum, hyoliths, bradoriids, and brachiopods). According to Steiner et al. (2007), the P. subangulata range Zone of the Qiongzhusian of South China appears to correlate with the $P$. lorenzi Zone of the middle-late Atdabanian of the Siberian Platform. Furthermore, the occurrence of $P$. subangulata, $R$. cancellatum, and M. effusum indicates a correlation with the Camenella baltica Zone of Avalonia and Newfoundland (Landing et al., 1980; Hinz, 1987; Landing, 1988). The occurrence of Pelagiella aff. P. subangulata and species of Microdictyon from the lower Montezuman Stage of the Montezuma Range section most probably corresponds with the bases of the taxon-range zones of South China, Siberia, and Avalonia. It therefore most probably identifies the base of Cambrian Series 2/Stage 3 in Nevada and enables the correlation of western Laurentia with these regions. However, the verification of SSF associations suitable for a global correlation of the basal Cambrian Series 2 needs further critical and comprehensive evaluation, as indicated by Landing et al. (2013).

\section{Acknowledgments}

We are grateful to P.G. Scholten (Show Low, Arizona) for his field assistance in July 2014. Special thanks to S. Niemeyer (University of Cologne) for her assistance in the lab and for microfossil hunting; H. Cieszynski (also Cologne) is thanked for SEM photography. We gratefully acknowledge the constructive comments of E. Landing (New York State Museum, Albany) and C.B. Skovsted (Swedish Museum of Natural History, Stockholm) and the editorial guidance of N.J. Butterfield (University of Cambridge). The research was financially supported by the German Research Foundation (WO 1215/6).

\section{References}

Albers, J.P., and Stewart, J.H., 1972, Geology and mineral deposits of Esmeralda County, Nevada: Bureau of Mines and Geology Bulletin, v. 78, 80 p.

Bengtson, S., and Conway Morris, S., 1992, Early radiation of biomineralizing phyla, in Lipps, J.H., and Signor, P.W., eds., Origin and Early Evolution of the Metazoan: Topics in Geobiology, v. 10, p. 447-482.

Bengtson, S., and Conway Morris, S., 2013, Early radiation of biomineralizing phyla, in Lipps, J.H., and Signor, P.W., eds., Origin and Early Evolution of the Metazoan: Topics in Geobiology, v. 10, p. 447-482.

Bengtson, S., and Missarzhevsky, V.V., 1981, Coeloscleritophora-a major group of enigmatic Cambrian metazoans, in Taylor, M.E., ed., Short papers from the Second International Symposium on the Cambrian System: US Geological Survey Open-File Report, v. 81-743, p. 19-21.

Bengtson, S., Matthews, S.C., and Missarzhevsky, V.V., 1986, The Cambrian netlike fossil Microdictyon, in Hoffmann, A., and Nitecki, M.H., eds., Problematic Fossil Taxa: Oxford, Oxford University Press, p. 97-115.

Bengtson, S., Conway Morris, S., Cooper, B.J., Jell, P.A., and Runnegar, B.N., 1990, Early Cambrian fossils from South Australia: Memoirs of the Association of Australian Palaeontologists, v. 9, 364 p.

Berg-Madsen, V., 1981, The Middle Cambrian Kalby and Borregård members of Bornholm, Denmark: Geologiska Föreningen I Stockholm Förhandlingar, v. 103, p. 201-231.

Betts, M., Paterson, J.R., Jago, J., Jacquet, S.M., Skovsted, C.B., Topper, T.P., and Brock, G.A., 2016, A new lower Cambrian shelly fossil biostratigraphy for South Australia: Gondwana Research, v. 36, p. 163-195.

Billings, E., 1872 (1871), On some new species of Palaeozoic fossils: The Canadian Naturalist and Quarterly Journal of Science, with proceedings of the Natural History Society of Montreal, v. 6, p. 213-222, 240. (p. 240 published 1871)

Chen, J.Y., and Zhou, G.Q., 1997, Biology of the Chengjiang fauna, in Chen, J.Y., Cheng, Y.N., and Van Iten, H., eds., The Cambrian Explosion and the Fossil Record: Bulletin of the National Museum of Natural Science, v. 10, p. 11-105.
Chen, J., Hou, X., and Lu, H., 1989, Early Cambrian netted scale-bearing wormlike sea animal: Acta Palaeontologica Sinica, v. 28, p. 1-16.

Cobbold, E.S., 1921, The Cambrian horizons of Comley and their Brachiopoda, Pteropoda, Gastropoda, etc.: Quarterly Journal of the Geographical Society of London, v. 76, p. 325-386.

Cuvier, G., 1797, Tableau élémantarie de l'histoire naturelle des animaux: Paris, Baudouin, $710 \mathrm{p}$.

Doré, F., and Reid, R.E., 1965, Allonnia tripodophora nov. gen., nov. sp., nouvelle eponge du Cambrien inférieur de Carteret (Manche): Comptes Rendus Sommaires des Séances de la Société Géologique de France, v. 1965 , p. $20-21$.

Duan, C.H., 1984, Small shelly fossils from the Lower Cambrian Xihaoping Formation in the Shennongjia District, Hubei Province- - hyoliths and fossil skeletons of unknown affinities: Bulletin of the Tianjin Institute of Geology and Mineral Resources, v. 7, p. 143-188. (in Chinese)

Dzik, J., and Krumbiegel, G., 1989, The oldest ‘onychophoran’ Xenusion: a link connecting phyla?: Lethaia, v. 22, p. 169-181.

Eddy, J.D., and McCollum, L.B., 1998, Early Middle Cambrian Albertella Biozone trilobites of the Pioche Shale, southeastern Nevada: Journal of Paleontology, v. 72, p. 864-887.

Eichwald, E., 1860, Lethaea Rossica ou Paléontologie de la Russie: Stuttgart, Schweizerbart, $1657 \mathrm{p}$.

Elicki, O., 1994, Lower Cambrian carbonates from eastern Germany: palaeontology, stratigraphy and palaeogeography: Neues Jahrbuch für Geologie und Paläontologie-Abhandlungen, v. 191, p. 69-93.

Elicki, O., 1996, Die Gastropoden und Monoplacophoren der unterkambrischen Görlitz Fauna: Freiberger Forschungshefte, C 464 - Paläontologie, Stratigraphie, Fazies, v. 3, p. 145-173.

Elicki, O., 2002, First record of Cambrian pelagiellids from Sardinia: Freiberger Forschungshefte, C 497 - Paläontologie, Stratigraphie, Fazies, v. 10, p. $19-27$.

Elicki, O., 2003, Das Kambrium Sachsens: Veröffentlichungen des Museums für Naturkunde Chemnitz, v. 26, p. 41-62.

Elicki, O., 2005, The utility of late Early to Middle Cambrian small shelly fossils from the western Mediterranean: Geosciences Journal, v. 9, p. 161-171.

Elicki, O., 2006, Microbiofacies analysis of Cambrian offshore carbonates from Sardinia (Italy): environment reconstruction and development of a drowning carbonate platform: Carnet de Géologie/Notebooks on Geology 2006/01, p. 1-22.

Elicki, O., 2011, First skeletal microfauna from the Cambrian Series 3 of the Jordan Rift Valley (Middle East): Memoirs of the Association of Australasian Palaeontologists, v. 42, p. 153-173.

Elicki, O., Hamann, Y., and Münzberger, P., 2003, Biofazies, Paläoökologie und Ablagerungsmodell des Finalstadiums einer kambrischen Karbonatplattform-Entwicklung: die Fauna der Campo Pisano Formation SW-Sardiniens: Freiberger Forschungshefte, C 499 - Paläontologie, Stratigraphie, Fazies, v. 11, p. $1-33$.

English, A.M., and Babcock, L.E., 2010, Census of the Indian Springs Lagerstätte, Poleta Formation (Cambrian), western Nevada: Palaeogeography, Palaeoclimatology, Palaeoecology, v. 295, p. 236-244.

Fisher, D.W., 1962, Small conoidal shells of uncertain affinities, in Moore, R.C., ed., Treatise on Invertebrate Paleontology, Part W, Miscellanea: Boulder, $\mathrm{CO}$ and Lawrence, KS, Geological Society of America and University of Kansas Press, p. W98-W143.

Geyer, G., 1986, Mittelkambrische Mollusken aus Marokko und Spanien: Senckenbergiana Lethaea, v. 67, p. 55-118.

Geyer, G., 1994, Middle Cambrian molluscs from Idaho and early conchiferan evolution: New York State Museum Bulletin, v. 481, p. 69-86.

Geyer, G., and Shergold, J., 2000, The quest for internationally recognized divisions of Cambrian time: Episodes, v. 23, p. 188-195.

Grabau, A.W., 1900, Palaeontology of the Cambrian terranes of the Boston Basin: Occassional Papers of the Boston Society of Natural History, v. 4, p. 601-694.

Grabau, A.W., and Shimer, H.W., 1909, North American Index Fossils Invertebrates, vol. 1: New York, A.G. Seiler \& Company, 909 p.

Gravestock, D.I., Alexander, E.M., Demidenko, Yu.E., Esakova, N.V., Holmer, L.E., Jago, J.B., Lin, T., Melnikova, L.M., Parkhaev, P.Yu., Rozanov, A. Yu., Ushatinskaya, G.T., Zang, W., Zhegallo, E.A., and Zhuravlev, A.Yu., 2001, The Cambrian biostratigraphy of the Stansbury Basin, South Australia: Transactions of the Palaeontological Institute, v. 282, 344 p.

Gubanov, A.P., 2002, Early Cambrian palaeogeography and the probable Iberia-Siberia connection: Tectonophysics, v. 352, p. 153-168.

Hao, Y.C., and Shu, D.G., 1987, The oldest well-preserved Phaecodaria (Radiolaria) from southern Shaanxi: Geoscience, v. 1, p. 301-310. (in Chinese)

He, T., Pei, F., and Fu, G., 1984, Some small shelly fossils from the Lower Cambrian Xinji Formation in Fangcheng county, Henan Province: Acta Palaeontologica Sinica, v. 23, p. 350-357. (in Chinese)

Hicks, H., 1872, On some undescribed fossils from the Menevian Group: The Quarterly Journal of the Geological Society of London, v. 28, p. 173-185. 
Hinz, I., 1987, The Lower Cambrian microfauna of Comley and Rushton, Shropshire/England: Palaeontographica Abteilung A, v. 198, p. 41-100.

Hollingsworth, J.S., 2005, Holmiidae (Trilobita: Olenellina) of the Montezuman Stage (Early Cambrian) in western Nevada: Journal of Paleontology, v. 80, p. 309-332.

Hollingsworth, J.S., 2011a, Lithostratigraphy and biostratigraphy of Cambrian Stage 3 in western Nevada and eastern California: Museum of Northern Arizona Bulletin, v. 67, p. 26-42.

Hollingsworth, J.S., 2011b, Stop 7D - The Base of the Fallotaspis Zone (base of the Montezuman Stage, Cambrian Stage 3), Montezuma Range: Nevada: Museum of Northern Arizona Bulletin, v. 67, p. 252-256.

Hollingsworth, J.S., and Babcock, L.E., 2011, Stop 8A - Base of Dyeran Stage (Cambrian Stage 4) in the middle member of the Poleta Formation, Indian Springs Canyon, Montezuma Range, Nevada: Museum of Northern Arizona Bulletin, v. 67, p. 256-275.

Horný, R.J., 1964, The Middle Cambrian Pelagiellacea of Bohemia (Mollusca): Sborník Národního Muzea v Praze, v. 20B, p. 133-140.

Hou, X.G., and Bergström, J., 1995, Cambrian lobopodians-ancestors of extant onychophorans?: Zoological Journal of the Linnean Society, v. 114 p. 3-19.

Jacquet, S.M., and Brock, G.A., 2016, Lower Cambrian helcionelloid macromolluscs from South Australia: Gondwana Research, v. 36, p. 333-358 doi: 10.1016/j.gr.2015.06.012.

Jago, J.B., Sun, X., and Zang, W.-L., 2002, Correlation within early Palaeozoic basins of eastern South Australia. South Australia: Department of Primary Industries and Resources. Report Book, 2002/33, 22 p.

Jago, J.B., Zang, W.-L., Sun, X., Brock, G.A., Paterson, J.R., and Skovsted, C.B., 2006, A review of the Cambrian biostratigraphy of South Australia Palaeoworld, v. 15 , p. $406-423$.

Khomentovsky, V.V., and Karlova, G.A., 1993, Biostratigraphy of the Vendian-Cambrian beds and the Lower Cambrian boundary in Siberia: Geological Magazine, v. 130, p. 29-45.

Klein, J.T., 1734, Naturalis dispositio Echinodermatum. Accesseit Lucubratiuncula de aculeis echinorum marinorum, cum Spicilegio de belemnitis Gedani (Gdansk), Schreiber, 79 p.

Knitter, H., 1979, Eine verbesserte Methode zur Gewinnung von Mikrofossilien aus harten, nicht schlämmbaren Kalken: Geologische Blätter für NordostBayern und angrenzende Gebiete, v. 29, p. 182-186.

Kobayashi, T., 1939, Restudy on Lorentz's Raphistoma broeggeri from Shantung with a note on Pelagiella: Jubilee Publication in Commemoration of Prof. H. Yabe's $60^{\text {th }}$ birthday, p. 283-288.

Kouchinsky, A., Bengtson, S., Clausen, S., and Vendrasco, M.J., 2015, An early Cambrian fauna of skeletal fossils from the Emyaksin Formation, northern Siberia: Acta Palaeontologica Polonica, v. 60, p. 421-512.

Landing, E., 1988, Lower Cambrian of eastern Massachusetts: stratigraphy and small shelly fossils: Journal of Paleontology, v. 62, p. 661-695.

Landing, E., and Bartowski, K.E., 1996, Oldest shelly fossils from the Taconic allochthon and late Early Cambrian sea-levels in eastern Laurentia: Journal of Paleontology, v. 70, p. 741-751

Landing, E., Nowlan, G.S., and Fletcher, T.P., 1980, A microfauna associated with Early Cambrian trilobites of the Callavia Zone, northern Antigonish Highlands, Nova Scotia: Canadian Journal of Earth Sciences, v. 17 , p. $400-418$.

Landing, E., Geyer, G., and Bartowski, K.E., 2002, Latest Early Cambrian small shelly fossils, trilobites, and Hatch Hill dysaerobic interval on the Québec continental slope: Journal of Paleontology, v. 76, p. 287-305.

Landing, E., Geyer, G., Brasier, M.D., and Bowring, S.A., 2013, Cambrian Evolutionary Radiation: context, correlation, and chronostratigraphyovercoming deficiencies of the first appearance datum (FAD) concept Earth-Science Reviews, v. 123, p. 133-172.

Laurie, J.R., 1986, Phosphatic fauna of the Early Cambrian Todd River Dolomite, Amadeus Basin, central Australia: Alcheringa, v. 10, p. 431-454

Li, G., Zhu, M., and Steiner, M., 2003, Microstructure and functional morphology of the Early Cambrian problematical fossil Rhombocorniculum: Progress in Natural Science, v. 13, p. 831-835.

Luo, H., Jiang, Z., Wu, X, Song, X., and Ouyang, L., 1982, The Sinian-Cambrian boundary in eastern Yunnan: People's Publishing House, Yunnan, 265 p. (in Chinese)

Malinky, J.M., 1988, Early Paleozoic hyolitha from North America: reexamination of Walcott's and Resser's type specimens: Journal of Paleontology, v. 62, p. 218-233.

Mambetov, A.M., 1972, A new Lower Cambrian hyolithid genus from Malyy Karatau (northwestern Tien Shan): Paleontological Journal, v. 6, p. 268-269.

Mambetov, A.M., and Missarzhevsky, V.V., 1972, New data on fossils from the phosphorite-bearing beds of Malyj Karatau: Precambrian stratigraphy of Kazakhstan and Tien Shan: Izdatelstvo MGU, Moscow, p. 217-221. (in Russian)
Marek, L., 1963, New knowledge on the morphology of Hyolithes: Sborník geologických věd, řada Paleontologie, v. 1, p. 53-72.

Matthew, G.F., 1894, Illustrations of the fauna of the St. John Group: Proceedings and Transactions of the Royal Society of Canada, v. 11, p. 85-129.

Matthew, G.F., 1895, The Protolenus fauna: Transactions of the New York Academy of Sciences, v. 14, p. 101-153.

McCollum, M.B., and McCollum, L.B., 2011, Depositional sequences in the Laurentian Delamaran Stage, southern Great Basin: U.S.A.: Museum of Northern Arizona Bulletin, v. 67, p. 154-173.

McCollum, L.B., McCollum, M.B., and Sundberg, F.A., 2011, Stops 5A, 5B $5 \mathrm{C}, 5 \mathrm{D}$, and $6 \mathrm{~A}$ - Discussion of the stratigraphy of the Laurentian Dyeran and Delamaran stage boundary interval in the Pioche-Caliente region: eastern Nevada, Museum of Northern Arizona Bulletin, v. 67, p. 215-226.

Meshkova, N.P., 1974, Lower Cambrian hyoliths of the Siberian Platform: Trudy Instituta Geologii i Geofiziki, Sibirskoe Otdelenie, Akademii Nauk SSSR, v. 97, p. 1-110. (in Russian)

Missarzhevsky, V.V., 1989, Oldest skeletal fossils and stratigraphy of Precambrian and Cambrian boundary beds: Trudy Geologicheskogo instituta Akademii Nauk SSSR, v. 443, p. 1-237. (in Russian)

Missarzhevsky, V.V., and Mambetov, A.M., 1981, Stratigraphy and fauna of the Precambrian-Cambrian boundary beds of Malyi Karatau: Trudy Geologicheskogo instituta Akademii Nauk SSSR, v. 326, p. 1-92. (in Russian).

Moore, J.L., Li, G., and Porter, S.M., 2013, Chancelloriid sclerites from the Lower Cambrian (Meishucunian) of eastern Yunnan, China, and the early history of the group: Palaeontology, v. 57, p. 833-878.

Nelson, C.A., 1962, Lower Cambrian-Precambrian succession, White-Inyo Mountains, California: Geological Society of America Bulletin, v. 73, $139-144$

Nötzold, T., 1965, Die Präparation von Gyrogoniten und kalkigen CharophytenOogonien aus festen Kalksteinen: Monatsberichte der Deutschen Akademie der Wissenschaften zu Berlin, v. 7, p. 216-221.

Palmer, A.R., 1971, The Cambrian of the Great Basin and adjacent areas, western United States, in Holland, C.H., ed., Cambrian of the New World: New York, Wiley Interscience, v. 99, p. 1-78.

Palmer, A.R., 1998, A proposed nomenclature for stages and series for the Cambrian of Laurentia: Canadian Journal of Earth Sciences, v. 35, p. 323-328.

Palmer, A.R., and Halley, R.B., 1979, Physical Stratigraphy and Trilobite Biostratigraphy of the Carrara Formation (Lower and Middle Cambrian) in the Southern Great Basin: Geological Survey Professional Paper, v. 1047, $131 \mathrm{p}$.

Parkhaev, P.Yu., 2001, Trenella bifrons: a new helcionelloid mollusk from the Lower Cambrian of South Australia: Paleontological Journal, v. 35, p. 22-24.

Parkhaev, P.Yu., 2014, Protoconch morphology and peculiarities of the early ontogeny of the Cambrian helcionelloid mollusks: Paleontological Journal, v. 48 , p. $369-379$.

Parkhaev, A.Yu., and Demidenko, Yu.E., 2010, Zooproblematatica and Mollusca from the Lower Cambrian Meishucun Section (Yunnan, China) and taxonomy and systematics of the Cambrian small shelly fossils of China: Paleontological Journal, v. 44, p. 883-1161.

Paterson, J.R., Skovsted, C.B., Brock, G., A., and Jago, J. B., 2007, An early Cambrian faunule from the Koolywurtie Limestone Member (Parara Limestone), Yorke Peninsula, South-Australia and its biostratigraphic significance: Memoirs of the Association of Australasian Palaeontologists, v. 34, p. 131-146.

Peel, J.S., 1991, Functional morphology of the Class Helcionelloida nov., and the early evolution of the Mollusca, in Simonetta, A., and Conway Morris, S., eds., The Early Evolution of Metazoa and the Significance of Problematic Taxa: Cambridge, Cambridge University Press and University of Camerino, p. 157-177.

Qian, Y., 1977, Hyolitha and some problematica from the Lower Cambrian Meishucun stage in central and S.W. China: Acta Palaeontologica Sinica, v. 16, p. 255-275. (in Chinese with English abstract)

Qian, Y., 1999, Taxonomy and Biostratigraphy of Small Shelly Fossils in China: Beijing. Science Press, 247 p. (in Chinese with English abstract)

Qian, Y., and Bengtson, S., 1989, Palaeontology and biostratigraphy of the Early Cambrian Meishucunian Stage in Yunnan Province: South China, Fossils and Strata, v. 24, p. 1-156.

Resser, C.E., 1938, Fourth contribution to the study of Cambrian fossils: Smithsonian Miscellaneous Collections, v. 97 (10), 43 p.

Resser, C.E., 1939, The Ptarmigania strata of the northern Wasatch Mountains: Smithonian Miscellaneous Collections, v. 98 (24), 84 p.

Rowell, A.J., 1966, Revision of some Cambrian and Ordovician inarticulate brachiopods: University of Kansas, Paleontological Contributions, v. 7 , p. $1-36$.

Rowell, A.J., 1977, Early Cambrian brachiopods from the southwestern Great Basin of California and Nevada: Journal of Paleontology, v. 51, p. 68-85. 
Rowell, A.J., 1980, Inarticulate brachiopods of the Lower and Middle Cambrian Pioche Shale of the Pioche District: Nevada, University of Kansas Paleontological Contributions, v. 98 , p. 1-25.

Rowell, A.J., and Henderson, R.A., 1978, New genera of acrotretids from the Cambrian of Australia and the United States: University of Kansas Paleontological Contributions, v. 93, p. 1-11.

Rozanov, A.Yu., Zhu, M., Pak, K.L., and Parkhaev, P.Yu., 2008, The $2^{\text {nd }}$ SinoRussian Symposium on the Lower Cambrian Subdivision: Paleontological Journal, v. 42, p. 441-446.

Runnegar, B., and Jell, P.A., 1976, Australian Middle Cambrian molluscs and their bearing on early molluscan evolution: Alcheringa, v. 1, p. 109-138.

Sdzuy, K., 1969, Unter- und mittelkambrische Porifera (Chancelloriida und Hexactinellida): Paläontologische Zeitschrift, v. 43, p. 115-147.

Signor, P.W., Mount, J.F., and Onken, B.R., 1987, A pre-trilobite shelly fauna from the White-Inyo region of eastern California and western Nevada: Journal of Paleontology, v. 61, p. 425-438.

Skovsted, C.B., 2004, Mollusc fauna of the Early Cambrian Bastion Formation of north-east Greenland: Bulletin of the Geological Society of Denmark, v. 51, p. $11-37$.

Skovsted, C.B., 2006a, Small shelly fossils from the basal Emigrant Formation (Cambrian, uppermost Dyeran Stage) of Split Mountain, Nevada: Canadian Journal of Earth Sciences, v. 43, p. 487-496.

Skovsted, C.B., 2006b, Small shelly fauna from the upper lower Cambrian Bastion and Ella Island formations, north-east Greenland: Journal of Paleontology, v. 80, p. 1087-1112.

Skovsted, C.B., and Holmer, L.E., 2006, The Lower Cambrian brachiopod Kyrshabaktella and associated shelly fossils from the Harkless Formation, southern Nevada: GFF, v. 128, p. 327-337.

Skovsted, C.B., and Peel, J.S., 2011, Hyolithellus in life position from the Lower Cambrian of North Greenland: Journal of Paleontology, v. 85, p. 37-47.

Smith, P.M., Brock, G.B., and Paterson, J.R., 2015, Fauna and biostratigraphy of the Cambrian (Series 2, Stage 4; Ordian) Tempe Formation (Pertaoorrta Group), Amadeus Basin, Northern Territory: Alcheringa, v. 39, p. 40-70.

Steiner, M., Li, G., Qian, Y., Zhu, M., and Erdtmann, B.-D., 2007, Neoproterozoic to early Cambrian small shelly fossil assemblages and a revised biostratigraphic correlation of the Yangtze Platform (China): Palaeogeography, Palaeoclimatology, Palaeoecology, v. 254, p. 67-90.

Stewart, J.H., 1970, Upper Precambrian and Lower Cambrian strata in the southern Great Basin, California and Nevada: U.S. Geological Survey Professional Paper, v. 620, 206 p.

Streng, M., and Holmer, L., 2006, New and poorly known acrotretid brachiopods (Class Lingulata) from the Cedaria-Crepicephalus zone (late Middle Cambrian) of the Great Basin: Geobios, v. 39, p. 125-153.

Streng, M., Babcock, L.E., and Hollingsworth, J.S., 2005, Agglutinated protists from the Lower Cambrian of Nevada: Journal of Paleontology, v. 79, p. $1214-1218$.

Sundberg, F.A., 2011, Delamaran biostratigraphy and lithostratigraphy of southern Nevada: Museum of Northern Arizona Bulletin, v. 67, p. 174-185.

Sundberg, F.A., and McCollum, L.B., 1997, Oryctocephalids (Corynexochida: Trilobita) of the Lower-Middle Cambrian boundary interval from California and Nevada: Journal of Paleontology, v. 71, p. 1065-1090.

Sundberg, F.A., and McCollum, L.B., 2000, Ptychopariid trilobites of the Lower-Middle Cambrian boundary interval, Pioche Shale, southeastern Nevada: Journal of Paleontology, v. 74, p. 604-630.

Sundberg, F.A., and McCollum, L.B., 2003a, Early and Mid Cambrian trilobites from the outer-shelf deposits of Nevada and California, USA: Palaeontology, v. 46, p. 945-986

Sundberg, F.A., and McCollum, L.B., 2003b, Trilobites of the lower Middle Cambrian Poliella denticulata Biozone (new) of southeastern Nevada: Journal of Paleontology, v. 77, p. 331-359.

Sundberg, F.A., McCollum, L.B., and McCollum, M.B., 2011, Stratigraphy of the Laurentian uppermost Dyeran Stage to Skullrockian Stage, Emigran Formation at Split Mountain, Esmeralda County, Nevada: Museum of Northern Arizona Bulletin, v. 67, p. 246-252.

Sysoiev, V.A., 1957, To the morphology, systematics and systematic position of the hyoliths: Doklady Akademii Nauk SSSR, v. 116, p. 304-307. (in Russian)

Tarsilli, A., and Warne, M.T., 1997, An improved technique for extracting calcareous microfossils from Palaeozoic limestones: Alchaeringa, v. 21, p. 57-64.
Tate, R., 1892, The Cambrian fossils of South Australia: Transactions of the Royal Society of South Australia, v. 15, p. 183-189.

Topper, T.P., Brock, G.A., Skovsted, C.B., and Paterson, J.R., 2009, Shelly fossils from the Lower Cambrian Pararaia bunyerooensis Zone, Flinders Ranges, South Australia: Memoirs of the Association of Australasian Palaeontologists, v. 37, p. 199-246

Topper, T.P., Brock, G.A., Skovsted, C.B., and Paterson, J.R., 2011 , Microdictyon plates from the lower Cambrian Ajax Limestone of South Australia: implications for species taxonomy and diversity: Alcheringa, v. 35 , p. $427-443$.

Ulrich, E.O., and Bassler, R.S., 1931, Cambrian bivalve Crustacean of the order Conchostraca: Proceedings of the United States National Museum, v. 78, $130 \mathrm{p}$.

Vendrasco, M.J., Kouchinsky, A.V., Porter, S.M., and Fernandez, C.Z., 2011, Phylogeny and escalation in Mellopegma and other Cambrian molluscs: Palaeontologica Electronica 14.2.11A, 44 p., palaeo-electronica.org/ 2011_2/221/index.html

Voronin, A.Yu., Voronova, L.G., Grigor'eva, N.V., Drozdova, N.A., Zhegaloo, E.A., Zhuravlev, A.Yu, Ragozina, A.L., Rozanov, A.Yu., Sayutina, T.A., Sysoev, V.A., and Fonin, V.D., 1982, The Precambrian-Cambrian boundary in the geosynclinal regions (reference section Salany-Gol, MNR): Trudy Sovmestnoj sovestko-mongol'skoj paleontologicheskoj ekspeditsiya, v. 18, 156 p. (in Russian)

Voronova, L.G., Drozdova, N.A., Esakova, N.V., Zhegallo, E.A., Zhuravlev, A. Yu., Rozanov, A.Yu., Sayutina, T.A., and Ushatinskaya, G.T., 1987, Lower Cambrian fossils from the Mackenzie Mountains (Canada): Trudy paleontologicheskogo instituta AN SSSR, v. 224, p. 1-88. (in Russian)

Walcott, C.D., 1886, Second contribution to the studies on the Cambrian faunas of North America: U.S. Geological Survey Bulletin, v. 30, 369 p.

Walcott, C.D., 1920, Middle Cambrian Spongiae: Smithsonian Miscellaneous: Collections, v. 67, p. 261-364.

Webster, M., 2011a, Trilobite biostratigraphy and sequence stratigraphy of the upper Dyeran (traditional Laurentian "Lower Cambrian") in the southern Great Basin: U.S.A.: Museum of Northern Arizona Bulletin, v. 67, p. $121-154$.

Webster, M., 2011b, Litho- and biostratigraphy of the Dyeran-Delamaran boundary interval at Frenchman Mountain, Nevada: Museum of Northern Arizona Bulletin, v. 67, p. 195-203.

Webster, M., 2011c, Litho- and biostratigraphy of the Dyeran-Delamaran boundary interval in the Pioche-Caliente region, Nevada: Museum of Northern Arizona Bulletin, v. 67, p. 203-215.

Webster, M., McCollum, L.B., and Sundberg, F.A., 2011, Upper Dyeran and Lower Delamaran lithostratigraphy and biostratigraphy of the northern Groom Range, Nevada: Museum of Northern Arizona Bulletin, v. 67, p. 226-236.

Wenz, W., 1938, Gastropoda. Allgemeiner Teil Prosobranchia, in Schindewolf, O.H., ed., Handbuch der Paläozoologie: Band 6, Gebrüder Borntraeger, Berlin, $720 \mathrm{p}$.

Wotte, T., 2006, New Middle Cambrian molluscs from the Láncara Formation of the Cantabrian Mountains (north-western Spain): Revista Española de Paleontología, v. 21, p. 145-158.

Xing, Y., Ding, Q., Luo, H., He, T., and Wang, Y., 1984, The Sinian-Cambrian Boundary of China: Bulletin of the Institute of Geology, Chinese Academy of Geological Sciences, v. 10, p. 1-262. (in Chinese)

Zadorozhnaya, N.M., Osadchaya, D.V., and Repina, L.N., 1973, New data on the Lower Cambrian biostratigraphy of the area around the village Bograd (Batney Hills), in Zhuravleva, I.T., ed., Problems of Lower Cambrian palaeontology and biostratigraphy of Siberia and Far East: Trudy Institut Geologii i Geofiziki, Sibirskoe Otdelenie, Akademii Nauk SSSR, v. 49, p. 119-151. (in Russian)

Zhang, X., and Aldridge, R.J., 2007, Development and diversification of trunk plates of the Lower Cambrian lobopodians: Palaeontology, v. 50, p. $401-415$.

Zhou, B., and Xiao, L., 1984, Early Cambrian monoplacophorans and gastropods from Huainan and Huoqiu Counties, Anhui Province: Professional Papers of Stratigraphy and Palaeontology, v. 13, p. 125-140. (in Chinese)

Accepted 21 February 2017 